\title{
Effects of water-soluble components of atmospheric particulates from rare earth mining areas in China on lung cancer cell cycle
}

Yuan $\mathrm{Xia}^{1+}$, Xulong Zhang ${ }^{2+}$, Dejun Sun ${ }^{3+}$, Yumin Gao ${ }^{1}$, Xiaoe Zhang ${ }^{1}$, Li Wang ${ }^{1}$, Qingjun Cai ${ }^{1}$, Qihao Wang ${ }^{1}$ and Juan Sun ${ }^{1 *}$

\begin{abstract}
Background: This study aims to investigate the effects of water soluble particulate matter (WSPM) on the viability and protein expression profile of human lung adenocarcinoma cell A549 in the Bayou Obo rare earth mining area, and explore the influence of WSPM on the A549 cell cycle.

Results: It was found that WSPM can inhibit the viability of A549 cells and induce cell arrest in the G2/M phase. Compared with controls, exposure to WSPM10 and WSPM2.5 induced 134 and 116 proteins to be differentially expressed in A549 cells, respectively. In addition, 33 and 31 differentially expressed proteins were further confirmed, and was consistent with the proteomic analysis. The most prominent enrichment in ribosome-associated proteins were presented. When RPL6, RPL13, or RPL18A gene expression was inhibited, A549 cells were arrested in the G1 phase, affecting the expression of Cyclin D1, p21, RB1, Cyclin A2, Cyclin B1, CDC25A, CDK2, CHEK2 and $E_{2} F_{1}$. Furthermore, the $\mathrm{La}^{3+}, \mathrm{Ce}^{3+}, \mathrm{Nd}^{3+}$ and $\mathrm{F}^{-}$in WSPM also inhibited the viability of A549 cells. After $24 \mathrm{~h}$ of exposure to $2 \mathrm{mM}$ of NaF, A549 cells were also arrested in the G2/M phase, while the other three compounds did not have this effect. These four compounds affected the cell cycle regulatory factors in A549 cells, mainly focusing on effecting the expression of CDK2, CDK4, RB1, ATM, TP53 and MDM2 genes. These results are consistent with the those from WSPM exposure.

Conclusions: These results revealed that WSPM from rare earth mines decreased the viability of A549 cells, and induced cell cycle G2/M phase arrest, and even apoptosis, which may be independent of the NF-kB/MYD88 pathway, and be perceived by the TLR4 receptor. The dysfunction of the cell cycle is correlated to the downexpression of ribosomal proteins (RPs). However, it is not the direct reason for the A549 cell arrest in the G2/M phase. $\mathrm{La}^{3+}, \mathrm{Ce}^{3+}$, and $\mathrm{F}^{-}$are probably the main toxic substances in WSPM, and may be regulate the A549 cell cycle by affecting the expression of genes, such as MDM2, RB1, ATM, TP53, $E_{2} F_{1}, C D K 2$ and CDK4. These results indicate the importance for further research into the relationship between APM and lung cancer.
\end{abstract}

\footnotetext{
*Correspondence: sj6840@163.com

${ }^{\dagger}$ Yuan Xia, Xulong Zhang and Dejun Sun contributed equally to this study. 'School of Public Health, Inner Mongolia Autonomous Region, Jinshan Economic and Technological Development Zone, Inner Mongolia Medical University, Inner Mongolia Autonomous Region 010010 Hohhot, China Full list of author information is available at the end of the article
}

(C) The Author(s). 2021 Open Access This article is licensed under a Creative Commons Attribution 4.0 International License, which permits use, sharing, adaptation, distribution and reproduction in any medium or format, as long as you give appropriate credit to the original author(s) and the source, provide a link to the Creative Commons licence, and indicate if changes were made. The images or other third party material in this article are included in the article's Creative Commons licence, unless indicated otherwise in a credit line to the material. If material is not included in the article's Creative Commons licence and your intended use is not permitted by statutory regulation or exceeds the permitted use, you will need to obtain permission directly from the copyright holder. To view a copy of this licence, visit http://creativecommons.org/licenses/by/4.0/ The Creative Commons Public Domain Dedication waiver (http://creativecommons.org/publicdomain/zero/1.0/) applies to the data made available in this article, unless otherwise stated in a credit line to the data. 
Keywords: Atmospheric particulates from rare earth mine, Lung cancer cell, Cell cycle, Quantitative proteomics, Ribosomal proteins

\section{Background}

Mining and smelting activities inevitably result in atmospheric particulate matter (APM) pollution and health hazard problems. Particulate matter contains a large amount of chemical elements, which include various toxic substances, such as heavy metals, rare earth elements (REE), radioactive elements, and polycyclic aromatic hydrocarbons (PAHs) [1]. Regardless of the indepth epidemiological studies, the potential mechanisms of APM-related adverse health effects are not fully understood [2,3]. The chemical composition of APM strongly depends on the geographic location and anthropogenic activities. Furthermore, many of these chemical components which are toxic and carcinogenic make numerous deleterious effects to human health [4]. In order to better understand the biological mechanisms involved in APM-associated cytotoxicity, special focus was given on the role of REE mine areas. The particulate matter samples were collected in Bayan Obo Mining District which is a mining town in west Inner Mongolia, China. This region has the world's largest deposits of rare-earth metals [5]. Large-scale mining, smelting and processing, air drying, less rain and strong wind have led to serious air particulate matter pollution in Bayan Obo, and a high REE background value in the atmospheric environment [6]. Tong et al. have found that the $\mathrm{PM}_{10}$ of Bayan Obo inhibited A549 cell viability, induced reactive oxygen species (ROS) production, and caused significant DNA damage [5]. In addition to the above mechanisms of cytotoxicity, it remains unclear whether there are other toxicity mechanisms.
In the present study, the potential toxicity of the water soluble particulate matter (WSPM) in A549 cells was investigated using approaches for molecular biology and cell biology. The toxicity effects of WSPM10 have been discerned on A549 cells by proteomics technology [7, 8]. This has the potential to identify previously unknown biomarkers, in order to gain insights into the mechanisms of toxicity. To our knowledge, the present study is the first time to provide details on the cytotoxicity of the WSPM in the Bayan Obo mining area.

\section{Results}

Chemical compositions and sources of WSPM in the Baotou Bayan Obo mining area

In WSPM10 and WSPM2.5, eight rare earth elements, seven heavy metal elements and nine watersoluble ions were detected. As shown in Fig. 1, the order of average concentration of REE in WSPM10 was as follows: $\mathrm{Ce}>\mathrm{Nd}>\mathrm{La}>\mathrm{Pr}>\mathrm{In}>\mathrm{Sm}>\mathrm{Gd}>\mathrm{Y}$. The order of average concentrations of heavy metal elements was as follows: $\mathrm{Fe}>\mathrm{Zn}>\mathrm{Cu}>\mathrm{Mn}>\mathrm{Cr}>$ $\mathrm{Pb}>\mathrm{Ni}$. As shown in Fig. 2, the five kinds of cationic average concentrations were as follows: $\mathrm{Na}^{+}>$ $\mathrm{Ca}^{2+}>\mathrm{K}^{+}>\mathrm{Mg}^{2+}>\mathrm{NH}_{4}{ }^{+}$. The average concentrations of the four anions presented in the following order: $\mathrm{SO}_{4}{ }^{2-}>\mathrm{Cl}^{-}>\mathrm{NO}_{3}{ }^{-}>\mathrm{F}^{-}$. In WSPM2.5, the average mass concentration and distribution rule of REE and heavy metal elements were similar to that of WSPM10, but were lower than that of WSPM10 as a whole. Furthermore, its average concentration of

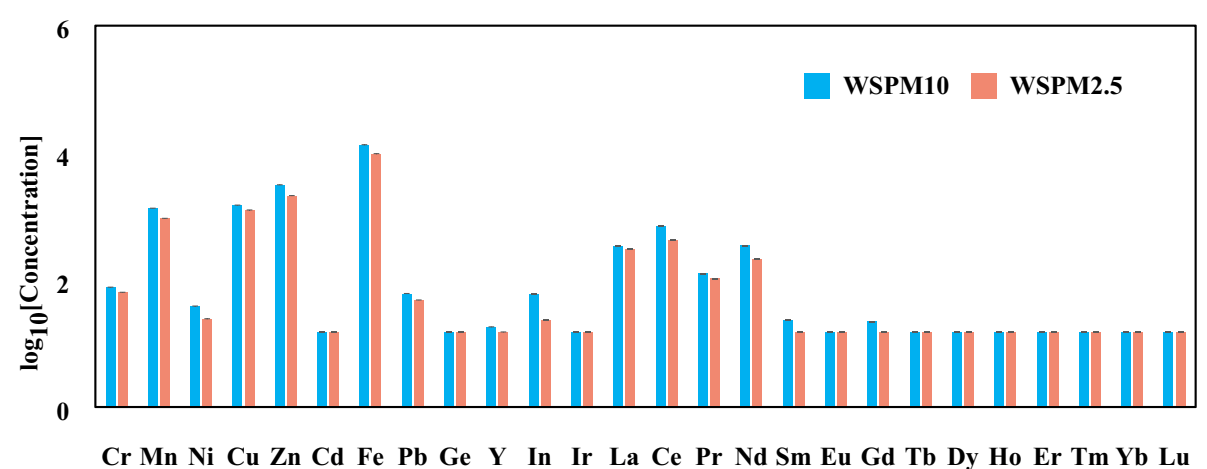

Type of element

Fig. 1 Content of metallic elements in WSPM10 and WSPM2.5. The abscissa represents the element species, while the ordinate represents the mass concentrations $(\mu \mathrm{g} / \mathrm{g}$ ) of the element (in log scale) in WSPM10 or WSPM2.5. The metallic elements of the samples were determined using inductively coupled plasma-atomic emission spectrometry. The power was $1.4 \mathrm{KW}$, the carrier gas flow rate was $1.0 \mathrm{~L} / \mathrm{min}$, the coolant flow was $15 \mathrm{~L} / \mathrm{min}$, the auxiliary flow was $1.0 \mathrm{~L} / \mathrm{min}$, and the pump speed was $1.5 \mathrm{~L} / \mathrm{min}$ 


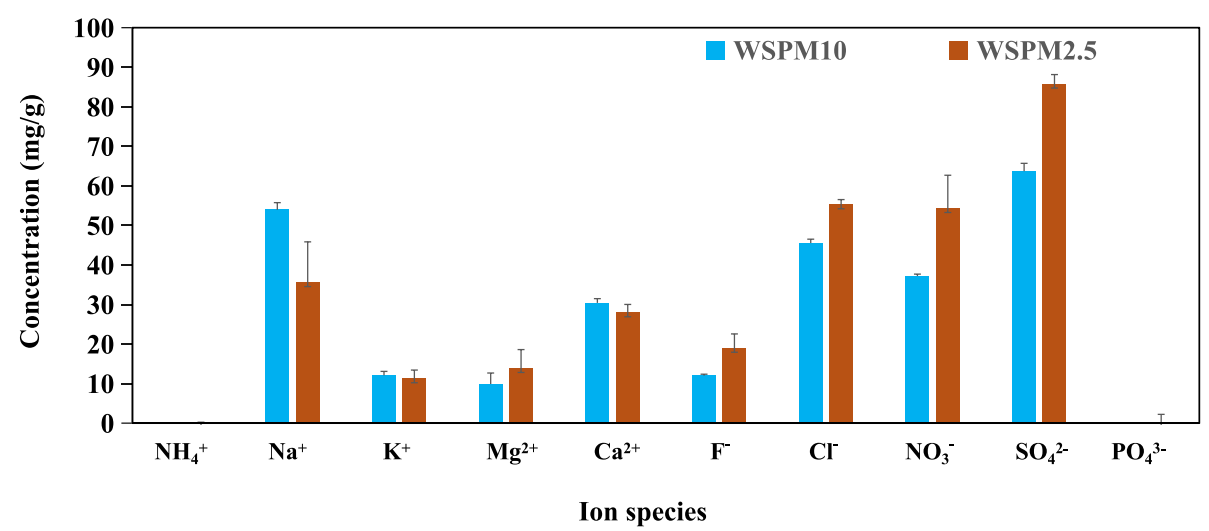

Fig. 2 Content of water soluble ions in WSPM10 and WSPM2.5. The abscissa represents the ion species, while the ordinate represents the ion mass concentration $(\mathrm{mg} / \mathrm{g})$ in WSPM10 or WSPM2.5. The determination of water soluble ion by suppressed ion chromatography was described in the samples

anion and cation was higher than WSPM10. Among the detected ions $\mathrm{SO}_{4}{ }^{2-}$ is the most abundant chemical component of both WSPM10 and WSPM2.5.

\section{WSPM inhibited A549 cell viability}

After the incubation of A549 cells with WSPM for 6, 24, 48 and $72 \mathrm{~h}$, the viability of A549 cells was significantly reduced compared with controls $(P<0.01)$. As shown in Fig. $3 \mathrm{~A}$, after treatment with WSPM10 on A549 cells for $6 \mathrm{~h}$, with increasing dose from 0 to $100 \mu \mathrm{g} / \mathrm{ml}$ the inhibition rate of cell viability also increased the dose of WSPM10 increased from 0 to $100 \mu \mathrm{g} / \mathrm{ml}$, and the inhibition rate of cell viability also increased. The inhibition rate reached nearly $15 \%$ when the dose reached $100 \mu \mathrm{g} / \mathrm{ml}(P<0.01)$. However, when the dose increased to $200 \mu \mathrm{g} / \mathrm{ml}$, the cell viability inhibition rate decreased to a certain extent $(P<$ 0.01 ). When the incubation time of WSPM10 was 24 or $48 \mathrm{~h}$, the dose of WSPM10 increased from 0 to $50 \mu \mathrm{g} / \mathrm{ml}$, and the cell viability inhibition rate reached approximately $20 \%(P<0.01)$. When exposure time was $72 \mathrm{~h}$, the inhibition rate of cell viability continued to increase with the increase in WSPM10 dose, and it reached nearly $40 \%$. When the WSPM10 dose was $200 \mu \mathrm{g} / \mathrm{ml}$, the inhibition rate of cell viability depended on the time of exposure.

As shown in Fig. 3B, after $6 \mathrm{~h}$ of incubation, the inhibition rate increased with the increase in WSPM2.5 dose, and the cell viability recovered to a certain extent when the concentration was $100 \mu \mathrm{g} / \mathrm{ml}$, but the difference was not statistically significant $(P>0.05)$. When the incubation time was 24,48 and $72 \mathrm{~h}$, the inhibition rate of A549 cell viability significantly increased with the increase in WSPM2.5 concentration, showing a dose-response relationship $(P<0.01)$. When the incubation time was 24 or $48 \mathrm{~h}$, compared with WSPM10 at the same dose, the WSPM2.5 group exhibited a stronger inhibition effect on cell viability as a whole.

\section{A549 cell cycle arrest in the G2/M phase was induced by WSPM}

To study the effects on cell cycle, A549 cells were treated with WSPM for $24 \mathrm{~h}$. With the increasing doses of WSPM, the proportion of G2/M cells rised, while G1 cells decreased. This indicates that WSPM induced the cell cycle arrest of A549 cells at the G2/M phase (Fig. 4, $\mathrm{S} 1$ and S2). G2/M arrest may be one of the reasons why WSPM inhibits the viability of A549 cells. Figures S1C, S1D and S2D present the obvious sub-G1 peak. With the increasing doses of WSPM, the signal of this peak became more obvious, indicating that some cells had apoptosis or necrosis during the exposure process. In general, A549 cells were exposed to different doses of WSPM for $24 \mathrm{~h}$, and each dose group exhibited a decrease in the proportion of G1 phase cells, and an increase in the proportion of $\mathrm{G} 2 / \mathrm{M}$ phase cells $(P<0.05)$.

\section{Cluster analysis of differentially expressed proteins(DEPs)}

In order to explore the cytotoxic effect on A549 cells during WSPM exposure, DEPs were screened by highthroughput isobaric Tags for Relative and Absolute Quantitation (iTRAQ)-based quantitative proteomic technology. A total of 2,453 proteins were identified and quantified with $>95 \%$ confidence interval $(\mathrm{CI})$ and false discovery rate (FDR) of $<1.0 \%$, and proteins with no less than one unique peptide were considered as positive identification. A 1.20-fold cutoff was established to detect DEPs (Figures S3 and S4). Afterwards, cluster analysis was performed to obtain the heatmap, which contains the dysregulated proteins (Fig. 5). Figure $5 \mathrm{~A}$ and $5 \mathrm{~B}$ present the clustering heatmaps of A549 cells exposed to WSPM10 and WSPM2.5 at different doses for $24 \mathrm{~h}$, respectively. 

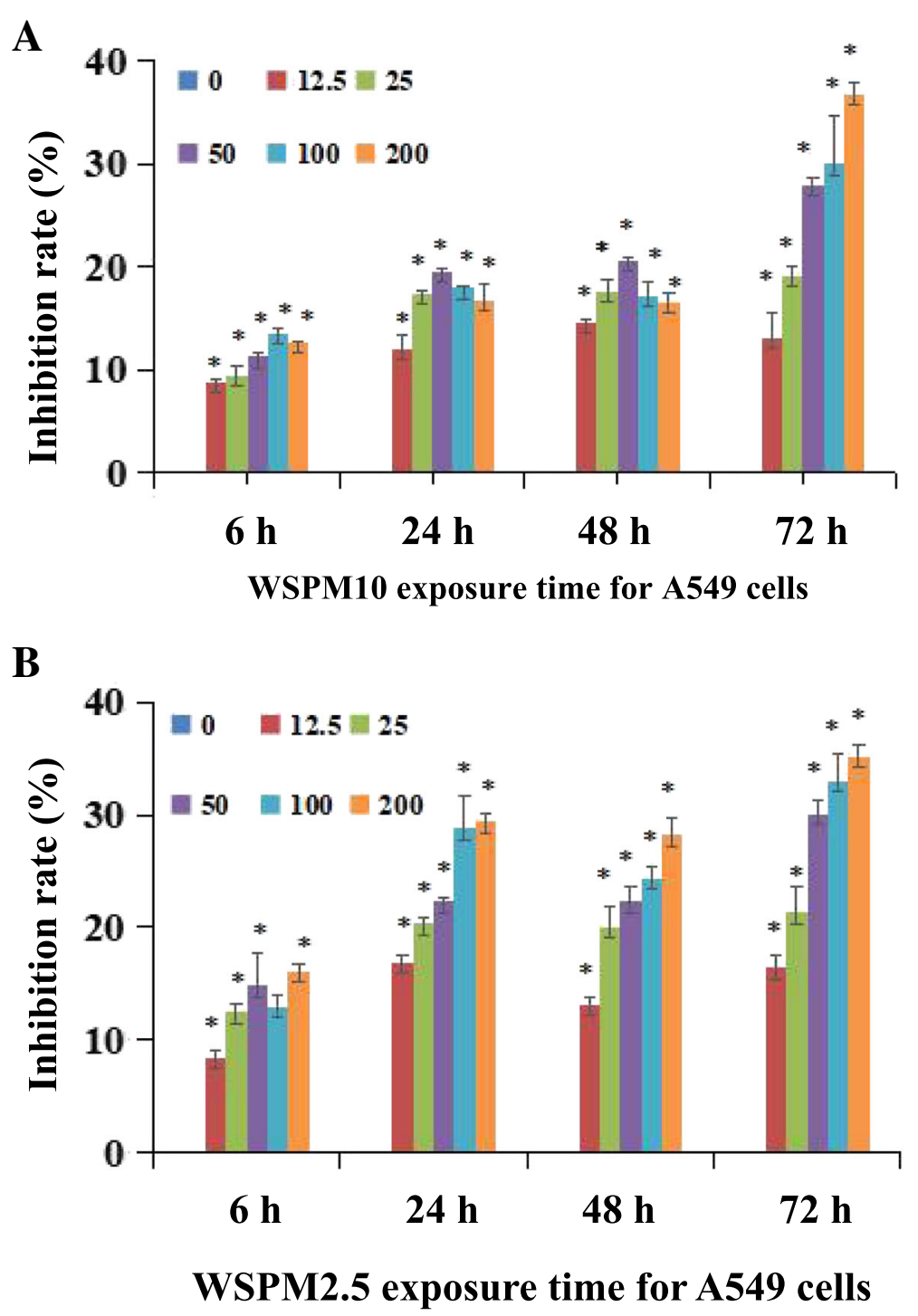

Fig. 3 The effect of WSPM on A549 cell viability. The abscissa represents the exposure time of WSPM to A549 cells, while the ordinate represents the cell viability inhibition rate (\%). A549 cells were treated by different concentrations (0, 12.5, 25, 100 and $200 \mu \mathrm{g} / \mathrm{ml}$ ) of WSPM10 (A) and WSPM2.5 (B) for 6, 24, 48 and 72 h, and cell viability was determined by MTT. The optical density value (OD) of samples were measured at 550 $\mathrm{nm}$. The cell viability inhibition rate $=(1-$ [OD of infected cells - background value] / [OD of control - background value] $) \times 100 \%$. The values shown on top of the bars represent the average of three individual experiments, and the standard errors are shown* WSPM with different concentrations was compared with the control group $(0 \mu \mathrm{g} / \mathrm{ml})$ at the same exposure time, $P<0.01$

It could be concluded that A549 cells exposed to different concentrations of WSPM10 correspond to different number DEPs. 27, 56, and 63 DEPs were observed in the $12.5,50.0$, and $200.0 \mu \mathrm{g} / \mathrm{ml}$ WSPM10 group, respectively. The cellular component (CC) analysis shows that the identified proteins mainly distributed in the cytosol, extracellular membrane-bounded organelles, cytosolic ribosomes, and so on. In the molecular function (MF) classification, the identified proteins that work as protein binding, poly(A) RNA binding and structural constituent of ribosomes which ranked at the top of the category. In the biological process (BP) category, proteins participated in the synthesis of nucleotides and purines, and performed functions, such as nucleic acid binding transcription factors and specific DNA binding transcription factors for the low dose group of WSPM10 $(12.5 \mu \mathrm{g} / \mathrm{ml})$. When the dose of WSPM10 was $50 \mu \mathrm{g} / \mathrm{ml}$, the majority of the identified proteins were classified into cell translation, mRNA synthesis, intracellular protein localization, and the disintegration of certain macromolecular substances. MF mainly focus on ribosome structural factors, structural molecular activities, iron ion binding proteins and heme binding proteins. When the dose of WSPM10 was further increased to $200 \mu \mathrm{g} /$ 

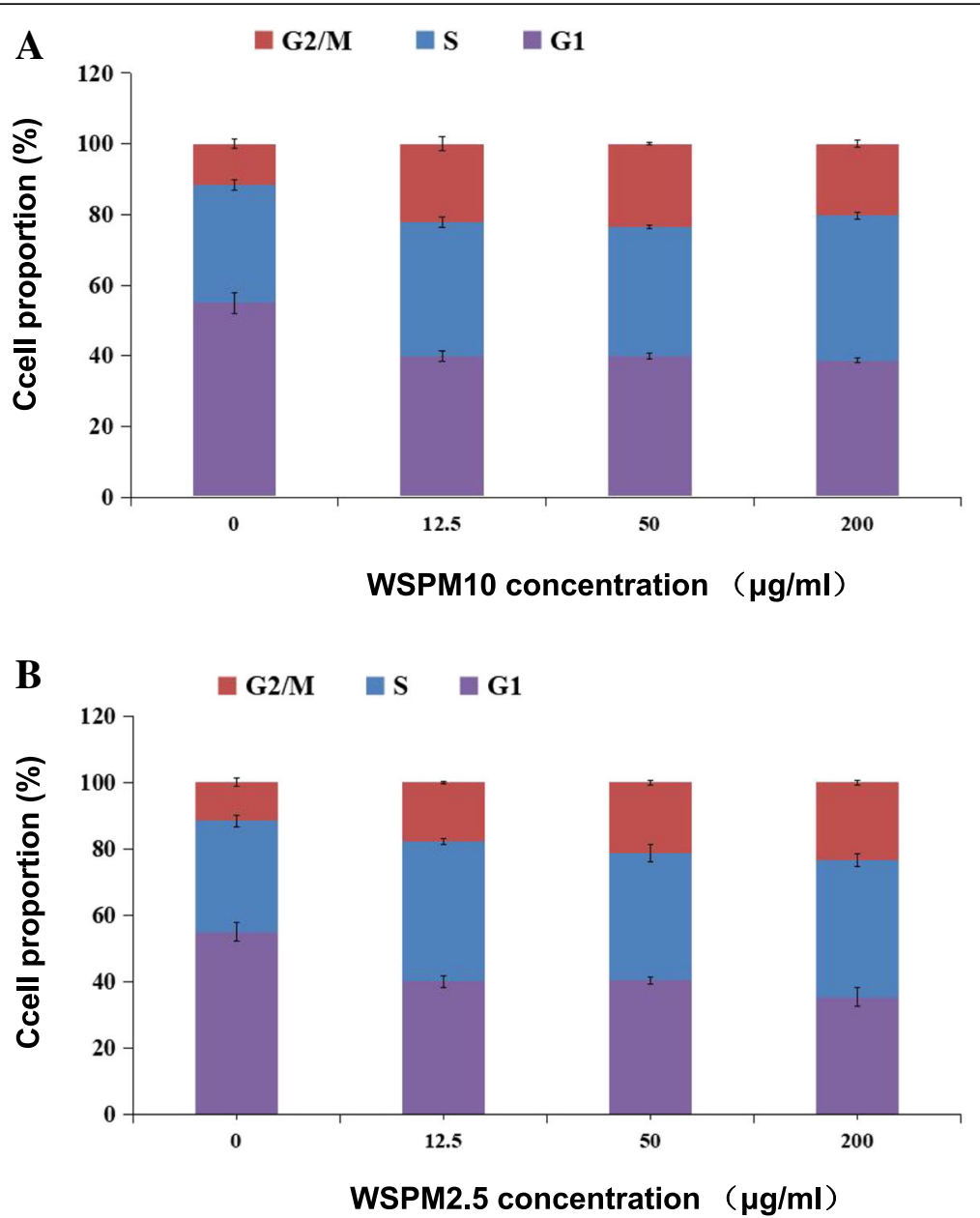

Fig. 4 Influence of the A549 cell cycle distribution treatment with different doses WSPM. (A) When A549 cells were treated with different concentrations of WSPM10, the cell proportion decreased in the G1 phase, while this increased in the G2/M phase. Cell cycle were arrested at the G2/M phase; (B) B shows the same effect as A. The values shown on top of the bars represent the average of three individual experiments, and the standard errors are shown

$\mathrm{ml}$, the biological enrichment pathway was similar to that of the $50 \mu \mathrm{g} / \mathrm{ml}$ group, and the MF mainly focused on ribosome structural composition factors, structural molecular activity, and RNA binding proteins (Figure S5; Tables S9, S10 and S11).

When the A549 cells were exposed to WSPM2.5 at a low dose $(12.5 \mu \mathrm{g} / \mathrm{ml})$, the DEPs were mainly distributed in the endoplasmic reticulum, nucleosome chromosomes and ribosomes, and most of the proteins participated in the response to external toxic substances, metal particles, nutrients, inorganic substances, nucleosome assembly, and chromosome assembly. The main molecular function was binding proteins. When the concentration of WSPM2.5 was $50 \mu \mathrm{g} / \mathrm{ml}$, the DEPs were mainly concentrated in the cytoplasm, especially in large molecular complexes, such as ribosomes, and most of which were involved in the synthesis, assembly, localization and disassembly of intracellular proteins, and in the synthesis of mRNA. Molecular functions are mainly focused on the binding of transition metals, and the assembly of ribosomes and RNA binding proteins. When the concentration of WSPM2.5 was $200 \mu \mathrm{g} / \mathrm{ml}$, the enrichment pathway was similar to that of the $50 \mu \mathrm{g} / \mathrm{ml}$ group, and the MF mainly focused on ribosome structural factors and metal-binding proteins (Figure S6; Tables S12, S13 and S14).

By comparing the different dose groups of the same particle, the WSPM dose significantly influenced the number and types of DEPs. At low doses $(12.5 \mu \mathrm{g} / \mathrm{ml})$, DEPs were mainly enriched in the response to nutrients and the function of nucleotide anabolism. However, with the increase in WSPM dose $(50 \mu \mathrm{g} / \mathrm{ml})$, the RNA catabolism mechanism and enrichment of cell alienation function in vivo manifested. When the dose was $200 \mu \mathrm{g} /$ $\mathrm{ml}$, the external stimulation exceeded the tolerance limit 


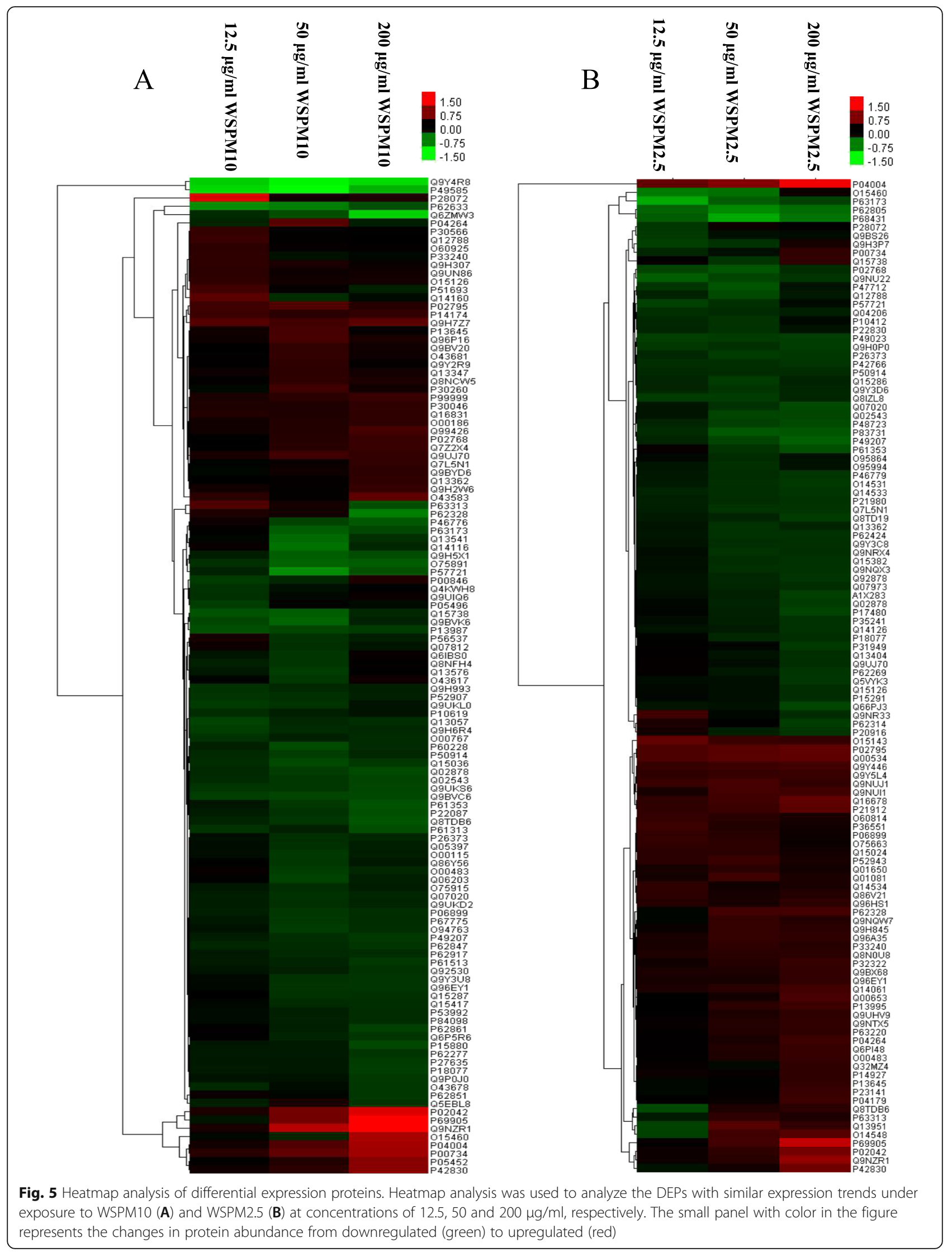


of the cell, and the stress response was inadequate for the pressure of the external environment, which damages the structure of large molecules, such as DNA and protein, and the ion channel dysfunction, resulting in the change in cell membrane potential. In addition, rare earth or heavy metal elements in particulate matter bind with intracellular proteins, and inactivate these. All these changes in biological functions based on the GO enrichment analysis, but the specific process needs to be further verified.

\section{Significant enrichment pathway analysis of DEPs}

DEPs were annotated into the KEGG database to obtain the involved signaling pathways or biological metabolic pathways. Among these, a total of 23 pathways were involved in the $12.5 \mu \mathrm{g} / \mathrm{ml} \mathrm{WSPM10}$ group, and the enrichment pathways were arranged according to their significance from high to low $(P<$ $0.05)$, as follows: the renin-angiotensin system, the fanconi anemia pathway, and the steroid biosynlife pathway (Table S15). The $50 \mu \mathrm{g} / \mathrm{ml}$ WSPM10 group involved 75 pathways. According to the significance $(P<0.05)$, the enrichment of pathways, in descending order, was as follows: the ribosome, malaria, african trypanosomiasis, tuberculosis, staphylococcus aureus infection, virus causing cancer, the p53 signaling pathway, muscle atrophy, amyotrophic lateral sclerosis, colorectal cancer, apoptosis, RNA transshipment, and ErbB signaling pathways (Table S16). A total of 57 pathways were involved in the $200 \mu \mathrm{g} / \mathrm{ml}$ WSPM10 group, and the enrichment pathways were arranged from high to low, as follows: ribosome, complement and coagulation cascade (Table S17).

A total of 91 pathways were involved in the $12.5 \mu \mathrm{g} / \mathrm{ml}$ WSPM2.5 group, and the enrichment pathways were arranged from high to low, as follows: systemic lupus erythematosus, alcohol poisoning, virus causing cancer, cholesterol synthesis, cancer disorders, the vascular endothelial growth factor (VEGF) signaling pathway, linoleic acid metabolism, chemokine signaling pathways, alpha linoleic acid metabolism, Ras signaling pathways, steroid biosynthesis, inflammatory bowel disease, the silk crack original activated protein kinase (MAPK) signaling pathway, human $\mathrm{T}$ lymphocyte virus type-1 infection, cocaine addiction, and steroid hormone biosynthesis (Table S18). The $50 \mu \mathrm{g} /$ $\mathrm{ml}$ WSPM2.5 group involved 57 pathways. The significant enrichment of channel was as follows (from high to low): the ribosome, alpha linoleic acid metabolism, the metabolism of cholesterol synthesis, linoleic acid, the phosphatidyl inositol 3 kinase/protein kinase B (PI3K/Akt) signaling pathway, and VEGF signaling pathways (Table S19). The $200 \mu \mathrm{g} / \mathrm{ml}$ WSPM2.5 group involved 77 pathways. The enrichment of channel, in descending order, was as follows: the ribosome, steroid biosynthesis, systemic lupus erythematosus (SLE), peroxisome, staphylococcal infections, glycosaminoglycan biosynthesis, and glycosphingolipid biosynthesis (Table S20).

According to the significant enrichment pathway analysis above, the most significant pathway was the ribosome pathway when the dose was $50 \mu \mathrm{g} / \mathrm{ml}$ and $200 \mu \mathrm{g} / \mathrm{ml}$ WSPM2.5 or WSPM10. Therefore, the DEPs involved in this pathway were selected as the objects of the follow-up studies.

\section{Verification of DEPs}

In the iTRAQ and multiple reaction monitoring (MRM) results, DEPs with the same expression trend were considered to meet the verification requirements, and the change value of the expression level was greater than 1.2 and $P<0.05$. Tables S3 and S4 illustrates the proteins detected using the MRM method in groups with different doses of WSPM10 and WSPM2.5, respectively, which met the verification requirements. Table S5 and Figure S11 presents the DEPs verified by western blot in the WSPM10 and WSPM2.5 groups.

\section{The downregulated expression of intracellular RPs affected the A549 cell cycle, but was an indirect factor of the $\mathrm{G} 2 / \mathrm{M}$ arrest}

According to the ITRAQ and MRM validation results, RPL6, RPL18A and RPL13 were all downregulated under WSPM10 and WSPM2.5 exposure conditions. HIS1H4A was also downregulated, but was only detected in the WSPM2.5 exposed group. In order to investigate their effects on the A549 cell cycle, siRNA interference with the expression of these genes were used to observe the relationship between their downregulated expression and the A549 cell cycle. As presented in Figure S8, compared with the negative control (NC) group, the transfection of siRNA RPL6-1, siRNA RPL18a-1 and siRNA RPL13-1 significantly reduced the levels of RPL6, RPL18A and RPL13 mRNA, and the inhibition rate reached over $90 \%(P<0.05)$. After transfection with siRNA HIS1H4A-3, HIS1H4A mRNA level decreased by $>80 \% \quad(P<0.05)$. Therefore, siRNA RPL6-1, siRNA RPL18a-1, SiRNA RPL13-1 and siRNA HIS1H4A-3 were selected for functional studies in subsequent cell transfection experiments. Compared with the $\mathrm{NC}$ group, the distribution of the A549 cell cycle before and after the interference of the four genes, there was no statistically significant difference in the proportion of cells in the G2/M phase $(P>0.05$, Fig. 6$)$. As presented in Figure S8 and Table S6, and compared with the NC group, when the RPL13, RPL6 and RPL18A gene expression was disturbed, the A549 cell cycle was arrested at the G1 phase $(P<0.01)$. Furthermore, the proportion of cells 


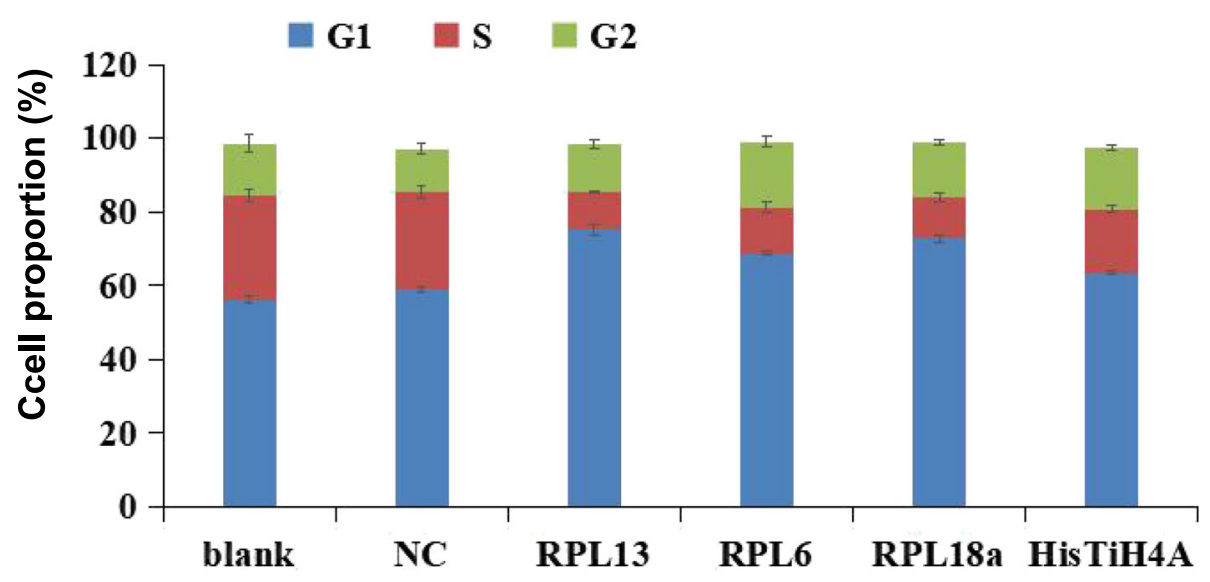

Fig. 6 Influence of gene interference on A549 cell cycle distribution. For all the interference groups, the cell proportion increased at the G1 phase, while this decreased at the S-phase. After the target gene was interfered, the cell cycle was arrested at the G1 phase. In the siRNA RPL13, siRNA RPL6 and siRNA RPL18A group, the proportion of A549 cells in the G1 phase was $75.08 \pm 2.21 \%, 68.72 \pm 0.63 \%$ and $72.75 \pm 1.62 \%$, respectively, which was higher than that in the blank group $(56.19 \pm 1.74 \%)$ and NC group $(59.73 \pm 0.66 \%)(P<0.01)$. The number of cells in the G1 phase in the siRNA HIS1H4A group was $63.41 \pm 0.94 \%$, but the difference was not statistically significant, when compared to the NC group $(P>0.05)$. Meanwhile, in the siRNA RPL13, siRNA RPL6, siRNA RPL18A and siRNA HIS1H4A groups, the proportion of A549 cells in the $S$ phase was $10.12 \pm 0.40 \%, 12.62 \pm 2.60 \%, 11.27 \pm 1.75 \%$, and $17.31 \pm 1.84 \%$, respectively, which was lower than those in the blank group (28.22 $\pm 3.01 \%)$ and NC group $(26.20 \pm 2.98 \%)(P<0.05)$

decreased in the $\mathrm{S}$ phase $(P<0.05)$. This suggests that when RPL13, RPL6 and RPL18A genes are disturbed, G1 phase arrest is induced in A549 cells. The proportion of cells in the $\mathrm{S}$ phase decreased in all gene interference groups $(P<0.05)$.

In previous validation experiments, it was confirmed that RPL13, RPL18A and RPL6 proteins were downregulated in A549 cells under the WSPM exposure process. Therefore, the downregulation of RPL13 and RPL18A genes effected the cell cycle regulation gene expression. As shown in Fig. 7, the expression of CCND1, CDKN1A and $R B 1$ were upregulated. Compared with the $\mathrm{NC}$ group, the expression levels of CCND1, CDKN1A and $R B 1$ in the siRNA RPL13 group increased by 1.5, 6.5, and 4.0 times, respectively $(P<0.01)$. In the siRNA RPL18A group, the expression of CCND1, CDKN1A and $R B 1$ increased by 2.0, 7.0, and 3.5 times, respectively $(P<0.01)$. In addition, CCNA2, CCNB1, CDC25A, $C D K 2, C H E K 2$ and $E_{2} F_{1}$ were downregulated in both groups. However, the expression of the TP53 gene increased by $12.5 \%$ in the siRNA RPL18A group $(P<$ $0.01)$, and was not significantly different from the other group $(P>0.05)$. Compared with the NC group, there were no significant differences in CCNE1, CDK4 and S100A4 $(P>0.05)$. When the RPL13 and RPL18A gene expression was disturbed, and compared with the NC group, the CCND1, CDKN1A and RB1 expression increased, while the CCNA2, CCNB1, CDC25A, CDK2, CHEK2 and $E_{2} F_{1}$ expression decreased. In the siRNA RPL13 group, compared with the NC group, ATM expression increased, while MDM2 expression decreased, and the differences were statistically significant $(P<$ $0.01)$. In the siRNA RPL18A group, compared with the NC group, the expression of TP53 increased $(P<0.01)$.

$\mathrm{F}^{-}, \mathrm{La}^{3+}$, and $\mathrm{Ce}^{3+}$ may be the main components of WSPM that causes cell cycle disturbance

In order to screen for major chemical risk factors in WSPM that cause A549 cell cycle disturbance, $\mathrm{LaCl}_{3}$, $\mathrm{CeCl}_{3}, \mathrm{NdCl}_{3}$ and $\mathrm{NaF}$ were selected as research subjects to observe their effects on A549 cell viability. Figure 8 shows that after the incubation of these four inorganic compounds for $24 \mathrm{~h}$, the viability of A549 cells significantly decreased, compared with the controls $(P<0.01$, Table S7).

After A549 cells were treated with $\mathrm{LaCl}_{3}, \mathrm{CeCl}_{3}, \mathrm{NdCl}_{3}$ and $\mathrm{NaF}$ for $24 \mathrm{~h}$, compared with the control group, the $\mathrm{LaCl}_{3}$ and $\mathrm{NdCl}_{3}$ exposed groups exhibited a slight change in cell proportion at the G1, S and G2/M phases, but the difference was not statistically significant $(P>$ 0.05). For the $\mathrm{CeCl}_{3}$ exposed group, the proportion of G1 phase cells exhibited a small decrease $(P<0.05)$, while the proportion of $\mathrm{S}$ phase cells increased $(P<$ 0.01 ). Although the proportion of $G 2 / M$ phase cells exhbited a decrease, the difference was not statistically significant $(P>0.05)$. For the NaF exposed group, compared with the controls, the proportion of G1 phase cells decreased by $11.62 \%$, while the proportion of cells at the $\mathrm{S}$ and $\mathrm{G} 2 / \mathrm{M}$ phase increased by 6.31 and $5.30 \%$, respectively $(P<0.01$; Fig. 9 , Table 88$)$.

In order to assess if the exposure to WSPM are associated with the expression of cell cycle regulators in A549 

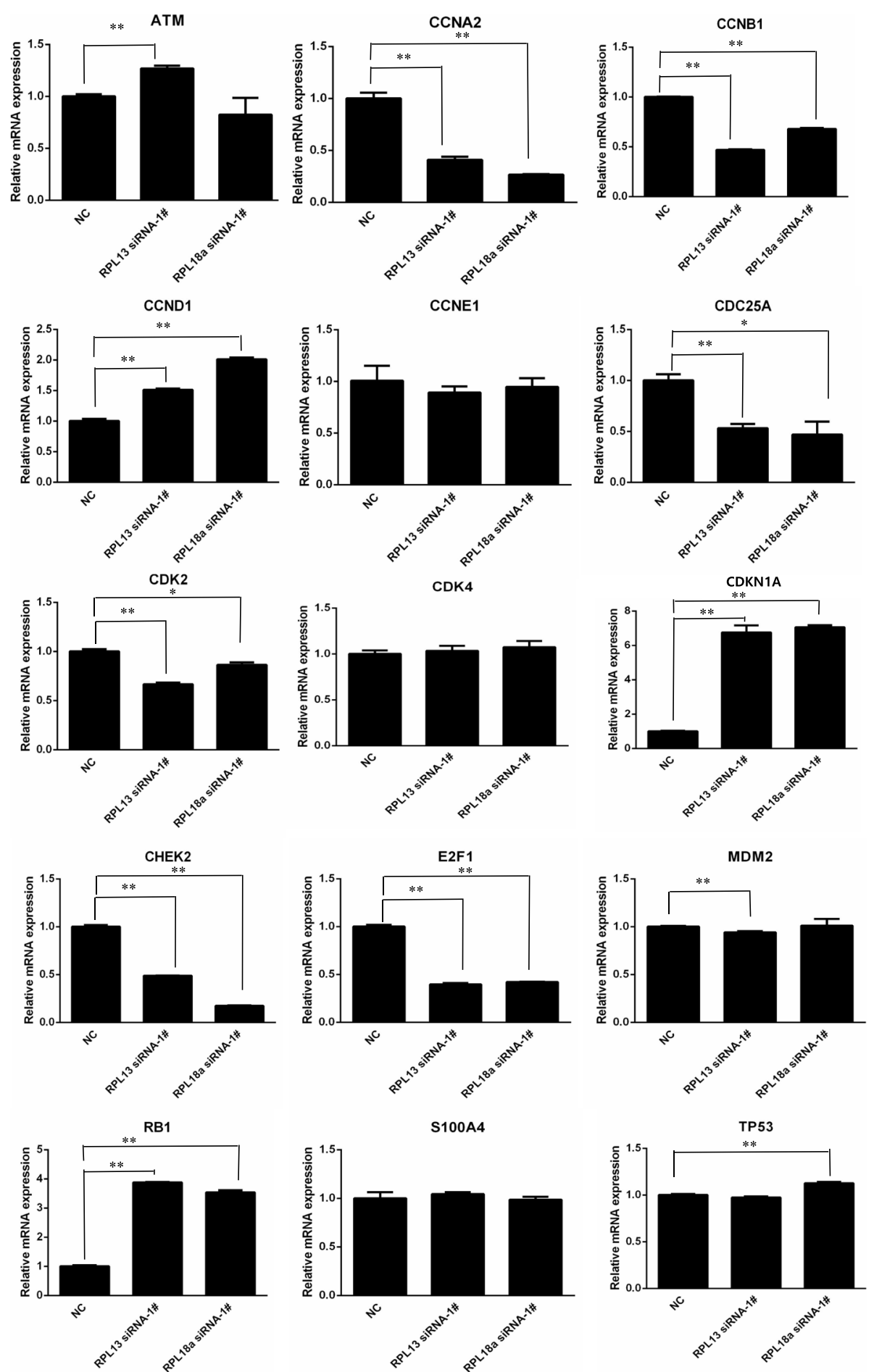

Fig. 7 Effects of RPL13 and RPL18A gene interference on the A549 cell cycle regulator expression. The abscissa represents the NC, siRNA RPL13 and siRNA RPL18A group, respectively, while the ordinate represents the relative expression quantity of the corresponding genes. The expression levels of 15 cell cycle regulators were measured by qRT-PCR at $24 \mathrm{~h}$ after siRNA transfection. ${ }^{*}$ Compared with the NC group, $P<0.05$;

${ }^{* *}$ Compared with the NC group, $P<0.01$

cells, the regulators which directly involved in the regulation of the cell cycle, were measured during WSPM exposure. As shown in Fig. 10, the ATM gene expression was upregulated in all exposure groups. The $A T M$ mRNA levels of the $\mathrm{LaCl}_{3}, \mathrm{CeCl}_{3}, \mathrm{NaF}, \mathrm{NdCl}_{3}$, WSPM2.5 and WSPM10 exposed groups were increased by 2.96 , 


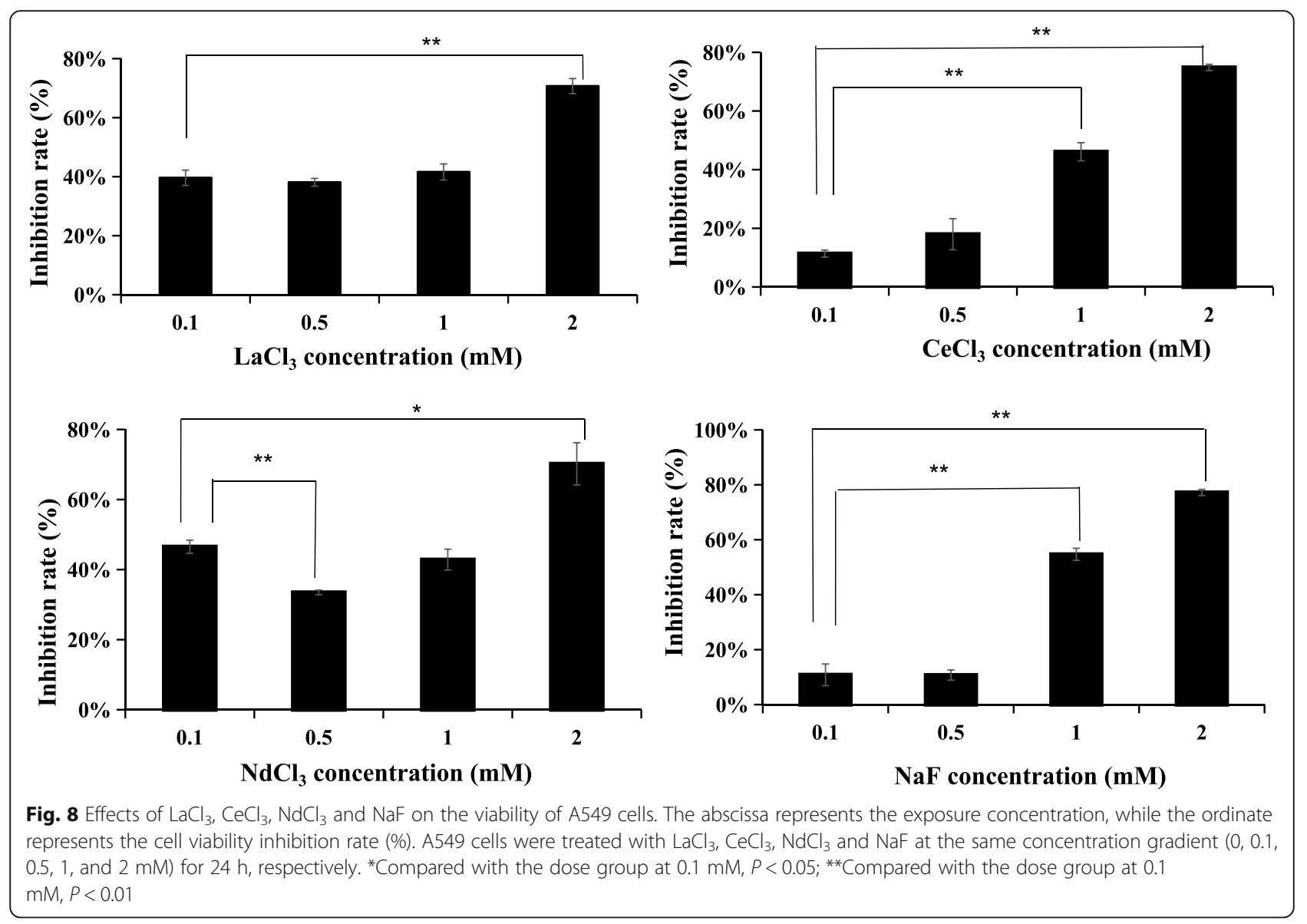

$4.22,4.67,1.33,3.09$, and 2.74 times compared with the control, respectively $(P<0.01)$. In addition, it was found that mRNA levels of RB1, TP53 and MDM2 were upregulated in the WSPM2.5 and WSPM10 groups $(P<0.05)$. The expression trend of cell cycle regulators in the $\mathrm{NaF}$ exposure group, was consistent with the WSPM2.5 and WSPM10 groups, which was mainly in $M D M 2, R B 1$, $A T M$, and TP53 genes. The mRNA levels of these genes were all upregulated $(P<0.05)$, among which the $\mathrm{NaF}$ group had a significantly higher change amplitude, compared with WSPM groups. On the other hand, the $\mathrm{LaCl}_{3}, \mathrm{CeCl}_{3}$ and $\mathrm{NdCl}_{3}$ groups also exhibited similarities in the mRNA expression trends of cell cycle regulators, which were mainly in the $C D K 2, C D K 4, C D K N 1 A$ and $A T M$ genes. Among these, the $\mathrm{CeCl}_{3}$ exposed group included 13 genes (11 upregulated and 2 downregulated

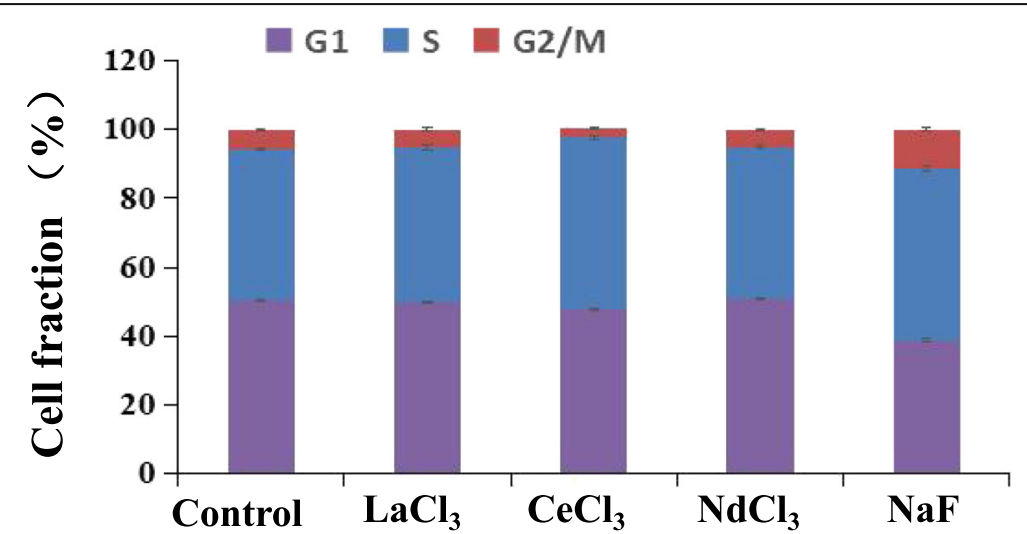

Fig. 9 Influence of $\mathrm{LaCl}_{3}, \mathrm{CeCl}_{3}, \mathrm{NdCl}_{3}$ and $\mathrm{NaF}$ on the A549 cell cycle distribution. When A549 cells were treated with $2 \mathrm{mM}$ of $\mathrm{NaF}$ for $24 \mathrm{~h}$, the cell cycle arrest was induced at the G2/M phase 


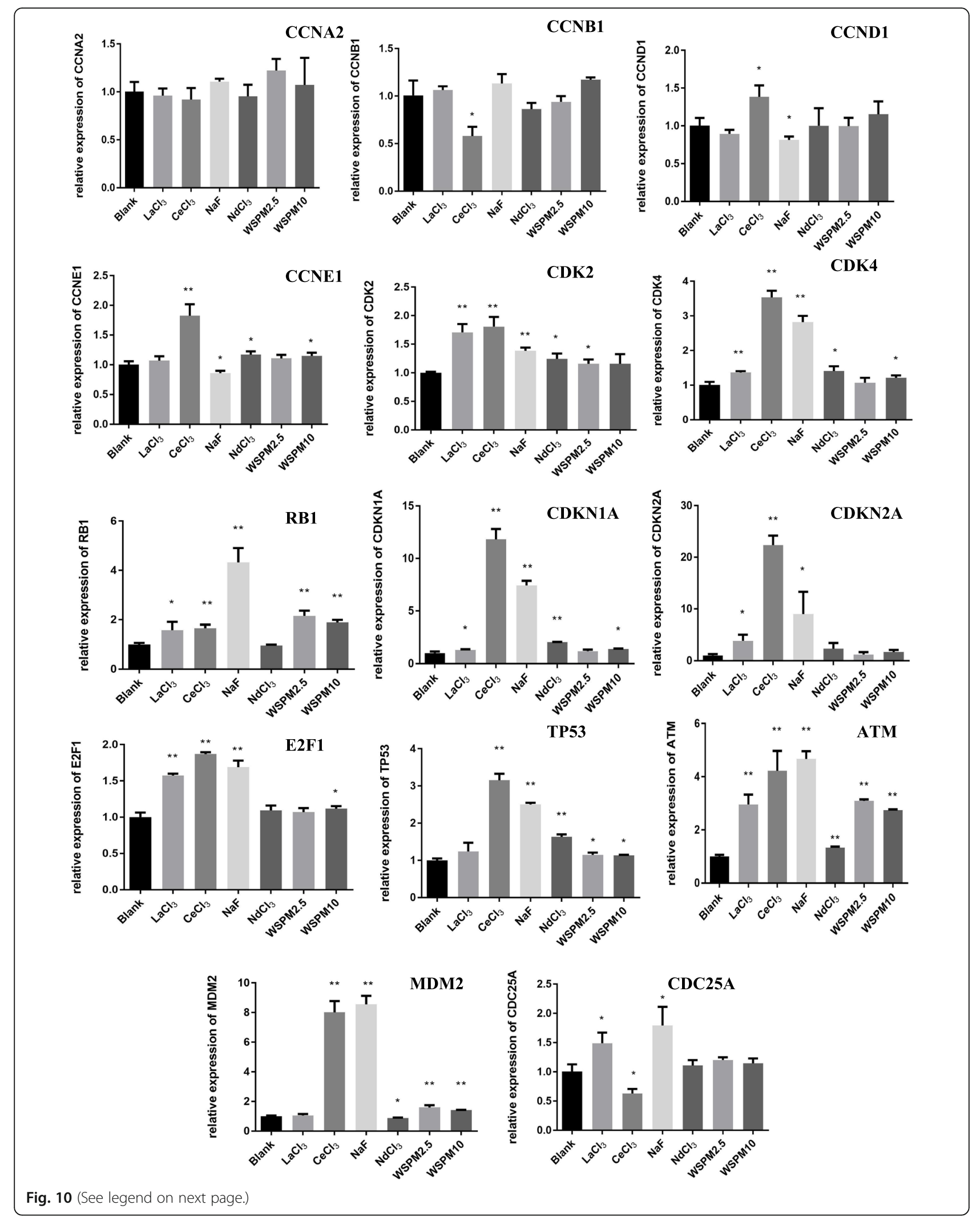


(See figure on previous page.)

Fig. 10 Effects of WSPM, $\mathrm{LaCl}_{3}, \mathrm{CeCl}_{3}, \mathrm{NdCl}_{3}$ and $\mathrm{NaF}$ on the $\mathrm{A} 549$ cell cycle regulator mRNA expression. The abscissa represents the blank control, $2 \mathrm{mM}$ of $\mathrm{LaCl}_{3}, 2 \mathrm{mM}$ of CeCl $3,2 \mathrm{mM}$ of NdCl $3,2 \mathrm{mM}$ of NaF, $200 \mu \mathrm{g} / \mathrm{ml}$ of WSPM2.5, and $200 \mu \mathrm{g} / \mathrm{ml}$ of WSPM10, from left to right, respectively, and the ordinate represents the relative expression quantity of the corresponding genes. A549 cells were treated with the above substances for $24 \mathrm{~h}$, and the expression of 14 kinds of cell cycle regulators were measured by qRT-PCR. ${ }^{*}$ Compared with the blank group, $P<$ $0.05 ;{ }^{* *}$ Compared with the blank group, $P<0.01$

genes), and 8 and 7 genes in the $\mathrm{LaCl}_{3}$ and $\mathrm{NdCl}_{3}$ exposed groups, respectively, which exhibited an upregulated expression $(P<0.05)$. In the $\mathrm{LaCl}_{3}$ and $\mathrm{CeCl}_{3}$ exposed groups, 7 genes exhibited the same expression trend, namely, $C D K 2, C D K 4, R B 1, C D K N 1 A, C D K N 2 A$, $E_{2} F_{1}$ and $A T M$. Meanwhile, the mRNA expression trend of $C D C 25 A$ was the opposite. However, the mRNA expression trends of 7 genes in the $\mathrm{NdCl}_{3}$ exposed group were completely the same as those in the $\mathrm{CeCl}_{3}$ group, namely, CDK2, CDK4, CCNE1, CDKN1A, TP53, MDM2 and $A T M$. As presented from the above results, $\mathrm{LaCl}_{3}$, $\mathrm{CeCl}_{3}, \mathrm{NaF}, \mathrm{NdCl}_{3}, \mathrm{WSPM} 2.5$ and WSPM10 have many similarities in their effects on the mRNA expression of cell cycle regulators, and have some characteristics of their own. As shown in Fig. 11 and Tabel S22, the protein level of ATM, CDK4, CDK2, $\mathrm{E}_{2} \mathrm{~F}_{1}, \mathrm{p} 21, \mathrm{p} 53$ and RB1 were upregulated in WSPM10 and WSPM2.5 exposure groups. This result is consistent in the transcription level. Conversely, MDM2 was decreased in WSPM2.5 exposure groups, but was slightly increased in WSPM10 exposure groups. On the other hand, ribosomal stress is induced by the impairment of ribosome biogenesis. The exposure of actinomycin $\mathrm{D}$ (Act $\mathrm{D}$ ) induced ribosomal stress, including the dysfunction of ribosome-free RPs and there RPs is involved in a multiple cellular processes such as MDM2-p53 signaling pathway and so on [9]. To investigate the changes in there cell cycle regulators levels induced by ribosomal stress which is caused by WSPM exposure, we treated cells with $5 \mathrm{nM}$ Act $\mathrm{D}$ for ribosomal stress positive control group. The protein levels of ATM, CDK4, p21, and p53 were upregulated sharply in Act D exposure groups, the protein levels of MDM2 and RB1 were decreased. At the same time, the protein level of $\mathrm{E}_{2} \mathrm{~F}_{1}, \mathrm{p} 21, \mathrm{p} 53$, and RB1 were upregulated in $\mathrm{CeCl}_{3}$, and $\mathrm{LaCl}_{3}$ exposure groups. The expression of ATM, $\mathrm{E}_{2} \mathrm{~F}_{1}, \mathrm{MDM} 2$, p21, and $\mathrm{RB} 1$ proteins was upregulated in $2 \mathrm{mM} \mathrm{NaF}$ exposure groups. It was consistent with their mRNA expression trends in $2 \mathrm{mM} \mathrm{NaF}$ exposure groups. But the increasing of there proteins level did not show a dose-dependent manner.

In addition, the effects of WSPM, $\mathrm{LaCl}_{3}, \mathrm{CeCl}_{3}, \mathrm{NdCl}_{3}$ and $\mathrm{NaF}$ on the expression of RPL13, RPL18A, TLR4 and MYD88 genes were investigated (Fig. 12). It was found that the $\mathrm{CeCl}_{3}$ and $\mathrm{NaF}$ exposure groups resulted in the upregulation of RPL13 gene expression, which increased by 10.66 and 3.07 times, respectively $(P<0.01)$. But in the WSPM10 and WSPM2.5 groups, it was reduced by $22.6 \%(P<0.05)$ and $49.0 \%(P<0.01)$, respectively. The expression of RPL13 gene was no different between the $\mathrm{LaCl}_{3}$ and $\mathrm{NdCl}_{3}$ exposure groups. For $R P L 18 A$, an upregulated gene was found in the $\mathrm{CeCl}_{3}$, $\mathrm{NdCl}_{3}$ and $\mathrm{NaF}$ exposure groups, which was increased by $8.29,3.88$ and 1.45 times, respectively. However, in the WSPM10 and WSPM2.5 exposure groups, RPL18A mRNA level decreased by $37 \%(P<0.01)$ and $27 \%(P<$ $0.01)$, respectively. On the other hand, the expression changes of TLR4, TLR2, SA and MYD88 genes were investigated to determine which membrane receptor responds to WSPM stimulation in A549 cells. TLR4 mRNA level was found to be upregulated in the $\mathrm{CeCl}_{3}$, $\mathrm{NaF}$ and WSPM2.5 exposure groups with an increase of 27.28 times $(P<0.01), 8.73$ times $(P<0.01)$ and 2.96 times $(P<0.05)$, respectively. Changes in CMYD88 mRNA level were merely observed in the $\mathrm{CeCl}_{3}$ exposure group, with a decrease of $49.0 \%(P<0.05)$.TLR2 and SA were not detected due to low expression levels (results were not listed).

\section{Effects of WSPM exposure on the expression of caspase 3,} 6,8 , and 9, and NF-KB in A549 cells

In the cell cycle analysis from the above results, it was found that after the high-dose WSPM10 and WSPM2.5 treatment for A549 cells for $24 \mathrm{~h}$, there was a sub-G1 peak, indicating that these cells may be apoptotic or necrotic. Hence, there is a need to understand the relationship of WSPM exposure and cell apoptosis. The intracellular expression quantity of caspase 3, 6, 8 and 9 were tested. It was found (Fig. 13) that the intracellular expression of caspase 3 was inhibited when the doses of WSPM10 or WSPM2.5 was $<100 \mu \mathrm{g} / \mathrm{ml}$, and this significantly increased when the dose reached $100 \mu \mathrm{g} / \mathrm{ml}$ or higher $(200 \mu \mathrm{g} / \mathrm{ml}) \quad(P<0.05)$. Caspase 8 and 9 were downregulated at all doses $(P<0.01)$. Caspase 6 expression was not statistically significant when the dose was $100 \mu \mathrm{g} / \mathrm{ml}$, when compared to the control group $(P>$ $0.05)$. When the dose was $200 \mu \mathrm{g} / \mathrm{ml}$, the expression was downregulated. In addition, when the expression of NF$\kappa B$ was analyzed, and it was found that WSPM exposure had no effect on the intracellular content of NF-kB (Figure S10). 


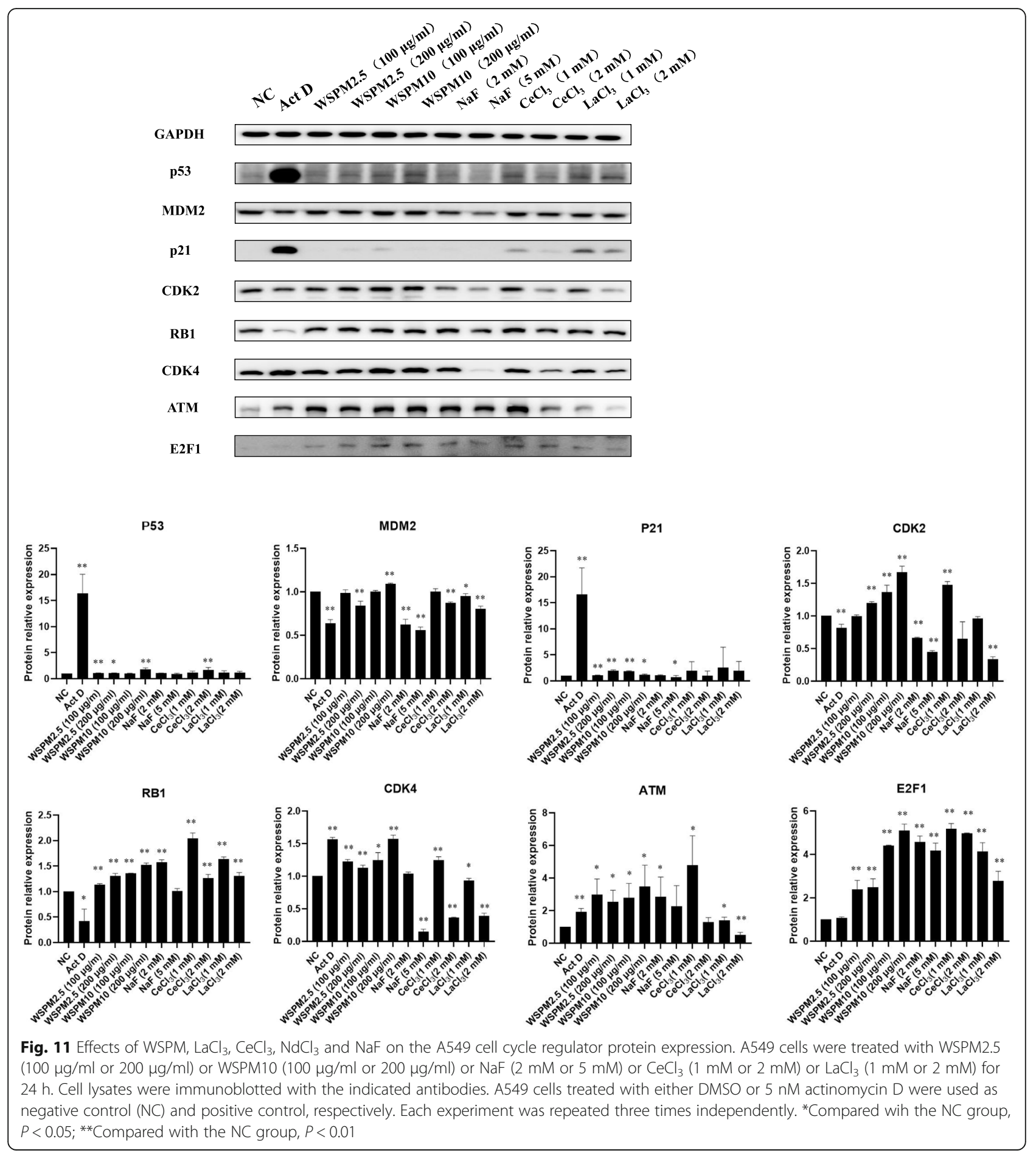

\section{Discussion}

The Baiyun Obo mining region is the most important light rare earth major producing areas in north China. The exploitation of resources has been going on for nearly a century, resulting in serious ecological pollution, rapid degradation of vegetation and worsening desertification [10]. The climate in this region is characterised by drought and low rainfall, and the dominant wind direction is northwest wind [10]. The chemical analysis results shown the distribution of rare earth elements in APM from this region is almost the same as that in soil $[11,12]$. In addition, when the weather is 

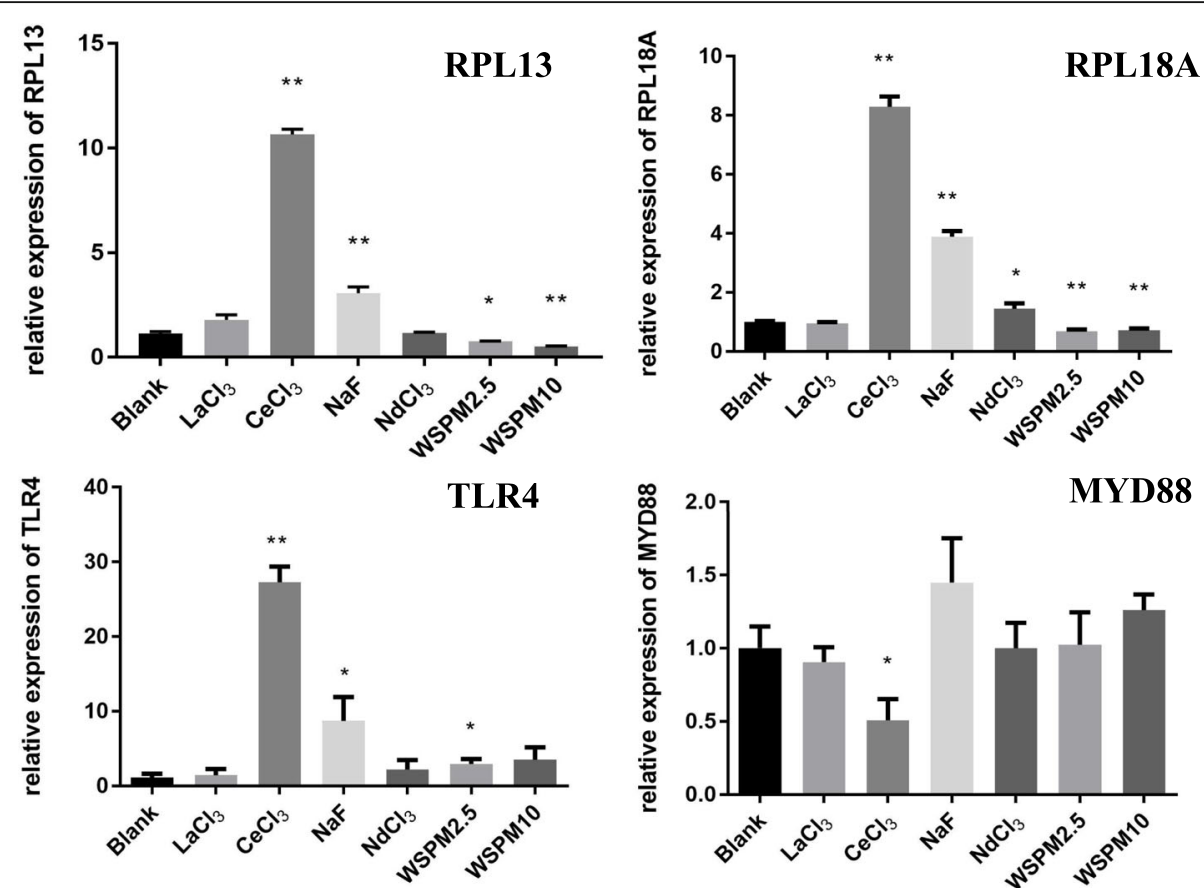

Fig. 12 Effects of WSPM, $\mathrm{LaCl}_{3}, \mathrm{CeCl}_{3}, \mathrm{NdCl}_{3}$ and NaF on the expression of RPL13, RPL18A, TLR4 and MYD88. The abscissa represents the blank control, $2 \mathrm{mM}$ of $\mathrm{LaCl}_{3}, 2 \mathrm{mM}$ of $\mathrm{CeCl}_{3}, 2 \mathrm{mM}$ of $\mathrm{NdCl}_{3}, 2 \mathrm{mM}$ of NaF, $200 \mu \mathrm{g} / \mathrm{ml}$ of WSPM2.5, and $200 \mu \mathrm{g} / \mathrm{ml}$ of WSPM10, from left to right, respectively, and the ordinate represents the relative expression quantity of the corresponding genes. A549 cells were treated with the above substances for $24 \mathrm{~h}$, and the expression of RPL13, RPL18A, TLR4 and MYD88 were measured by GRT-PCR. *Compared wih the blank group, $P<$ $0.05 ;{ }^{* *}$ Compared with the blank group, $P<0.01$

windy, the ground particles in the mining area would enter the atmosphere in the form of sand dust. In Baotou city, the concentration of PM10 and PM2.5 were 0. $432 \pm 0.722$ and $0.206 \pm 0.254 \mathrm{mg} / \mathrm{m}^{3}$ in 2005 , respectively, and has little changed from 2005 to 2006. In comparison with the non-sand-dust weather, the levels of PM10 and PM2.5 during sand-dust weather increased to some extent [12].

Some water-soluble ions, such as $\mathrm{SO}_{4}{ }^{2-}, \mathrm{NO}_{3}{ }^{-}$and $\mathrm{NH}_{4}{ }^{+}$, are the common components of secondary particulate matter, and their proportion in $\mathrm{PM}_{2.5}$ is regional, such as Nanjing (45.1\% in living areas, $42.9 \%$ in chemical areas, and $40.3 \%$ in traffic areas), Xiamen (24.4\%), Tianjin (33.4\%) and Zhengzhou (66.1\%) [13]. In our results, water-soluble ions in the Bayan Obo mining area account for 26.48 and $37.18 \%$ of $\mathrm{PM}_{10}$ and $\mathrm{PM}_{2.5}$, respectively, which is similar to the results of other studies. Ma et al. have shown that water soluble fraction constituted more than $39 \%$ of the PM2.5 which were collected from 10 urban cities in China [14]. The water-soluble inorganic ions in PM10 have also a greater proportion. but its proportion is affected by dust weather [15]. The mass of water-soluble fraction showed a clear spatial variation in different areas. It accounted for $15.7-46.9 \%$ of particle mass in the PM10 and 18.0-45.1\% of particle mass in the PM2.5, respectively [16].
WSPM2.5 has an obvious inhibitory effect on the viability of A549 cells. However, the inhibitory effect of WSPM10 was slightly different from WSPM2.5, and the cell viability inhibition is first increases and subsequently decreases with the increasing doses. This is somewhat different from the cytotoxicity of APM in other regions [17-21], which may be caused by differences in chemical composition of APM sample.

Compared with the controls, A549 cells were treated with WSPM10 or WSPM2.5 for $24 \mathrm{~h}$. With the increasing doses, the percentage of cell in $\mathrm{G} 2 / \mathrm{M}$ phase increased, and G1 phase cell fraction decreased. This resluts indicates that WSPM could block the A549 cell cycle to G2/M phase. G2/M arrest may be one of the reasons for the toxic mechanism of WSPM. Similar to the results in the present study, the G2/M arrest caused by APM exposure was also observed in other cells, including normal cells [22-25]. Longhin et al. found that Milan winter $\mathrm{PM}_{2.5}$ induced $\mathrm{G} 2 / \mathrm{M}$ arrest in the BEAS$2 \mathrm{~B}$ cell and augmented ROS formation. This effect is related to $\mathrm{PM}_{2.5}$ organic fraction, which cause damages to DNA [23]. However, WSPM in the Bayou Obo rare earth mining area which mainly contains inorganic component, can also induce A549 cell G2/M arrest and inhibit cell proliferation. In another study it was found that $\mathrm{PM}_{2.5}$ induced A549 cell cycle arrest in G2/M phase 

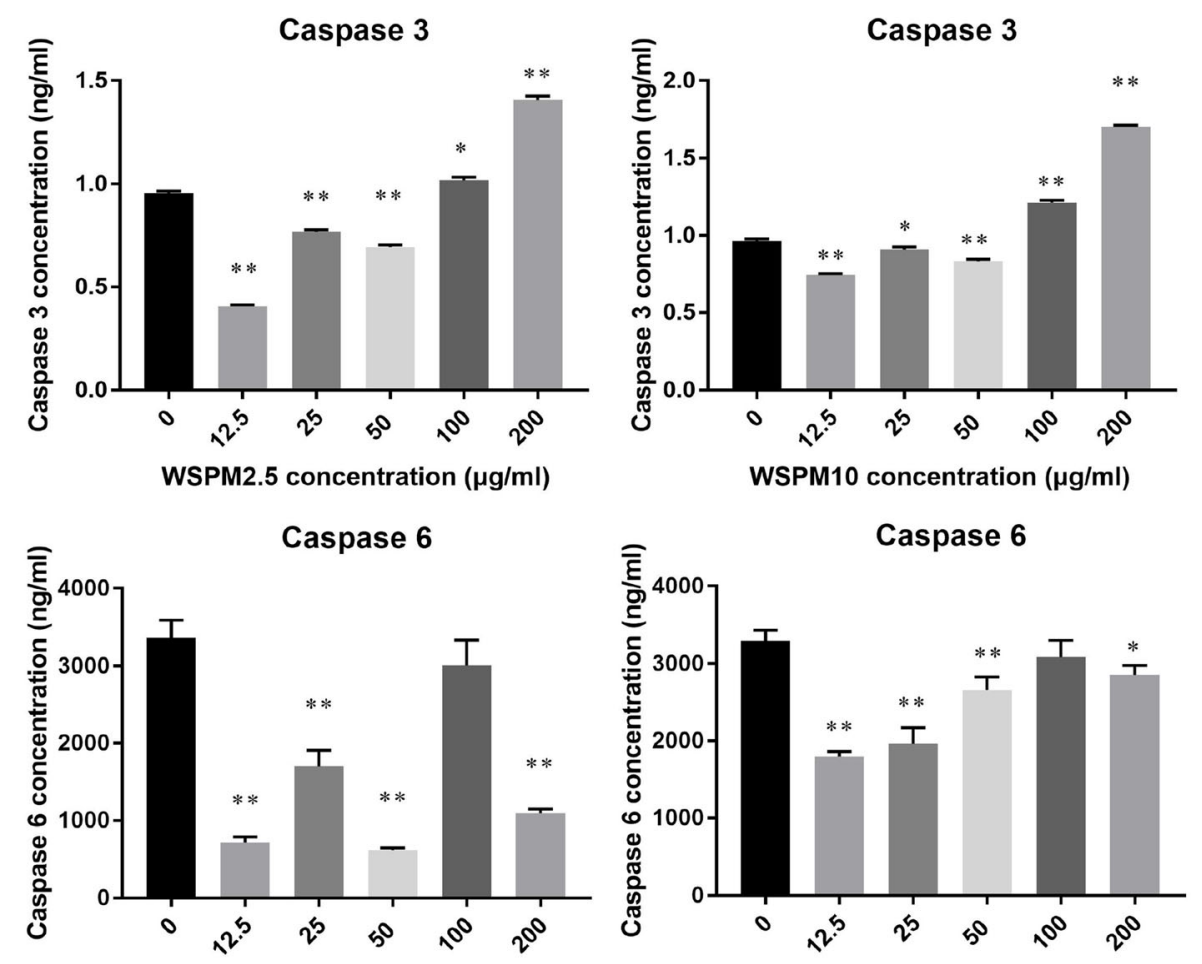

WSPM2.5 concentration $(\mu \mathrm{g} / \mathrm{ml})$
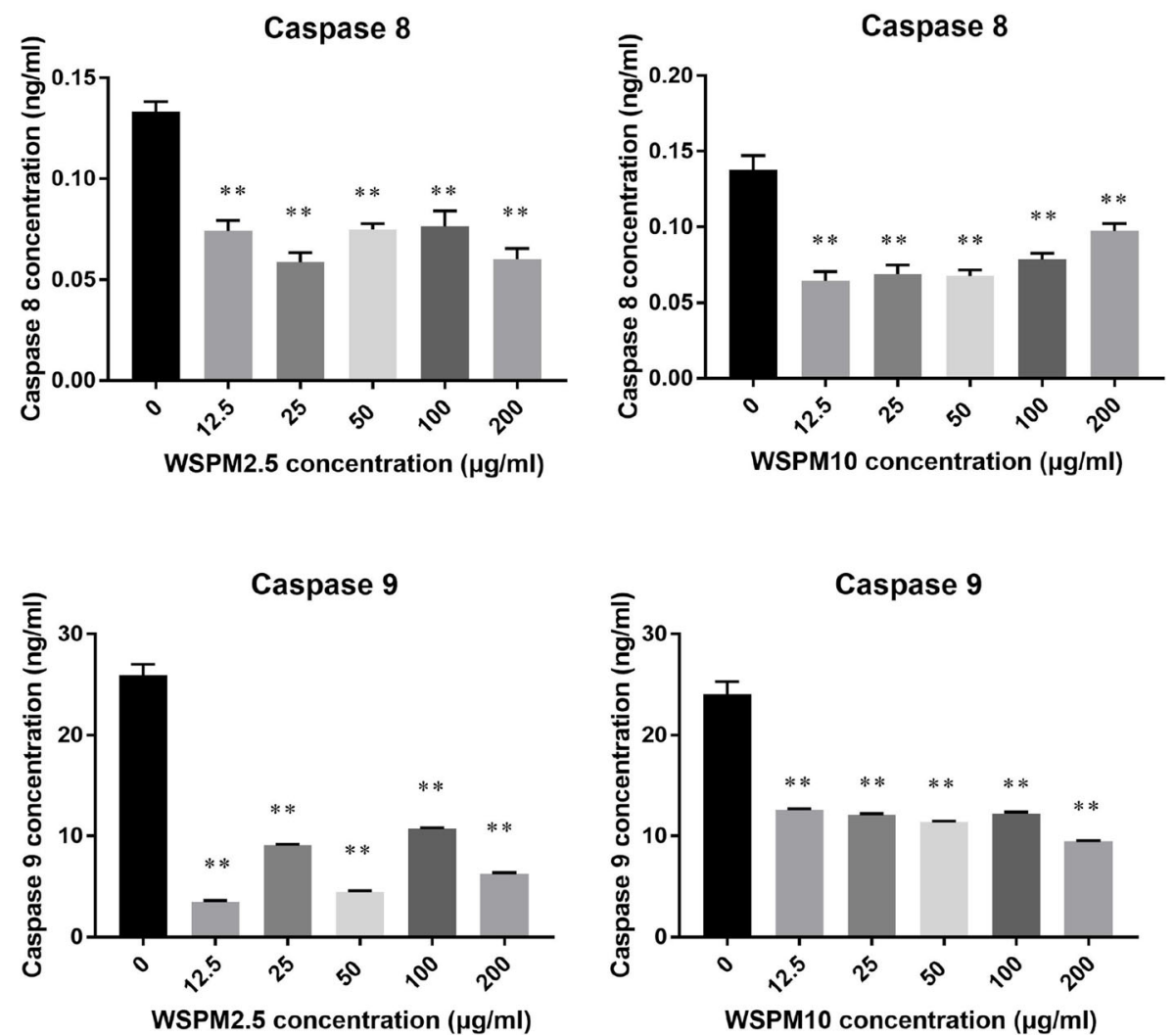

Fig. 13 (See legend on next page.) 
(See figure on previous page.)

Fig. 13 Effects of WSPM on the protein expression of caspase 3, 6, 8 and 9. The abscissa represents the exposure concentration of WSPM2.5 or WSPM10 $(0,12.5,25,50$ and $200 \mu \mathrm{g} / \mathrm{ml})$, while the ordinate represents the expression quantity of caspase 3, 6, 8 and 9 . A549 cells were treated with WSPM2.5 or WSPM10 for $24 \mathrm{~h}$, and the expression levels of caspase 3, 6, 8 and 9 were measured by ELISA (from top to bottom). ${ }^{*}$ Compared with the solvent control group $(0 \mu \mathrm{g} / \mathrm{ml}), P<0.05 ;{ }^{* *}$ Compared with the solvent control group $(0 \mu \mathrm{g} / \mathrm{ml}), P<0.01$

by upregulation of $p 53$ and $p 21$ and downregulation of CDK1 mRNA level [26]. To explore the potential mechanisms of this effect, the proteome techniques [27] were used to evaluate the cytotoxic effects of WSPM in this study. According to DEPs molecular function, the proven DEPs were classified into 6 categories (Table S21), namely, metabolism-related enzymes, signaltransduction-related proteins, proteins associated with detoxification and transcription translation, ribosome related proteins, calcium binding proteins, and cellular structure-related proteins. The DEPs of WSPM10 and WSPM2.5 exposed groups involved both common components and their own characteristics. In general, ribosomal related proteins, had the highest degree of overlap in the two exposed groups, which included seven downregulating RPs. In addition to protein synthesis, some RPs have non-protein synthesis functions (also known as extraribosomal functions [28]), including DNA transcription and repair [29], cell proliferation, cell cycle arrest, and apoptosis [30-32]. Furthermore, the expression of some RPs is inhibited without affecting cell protein synthesis $[28,33]$. By interfering with the RPL13, RPL6, and RPL18A gene expression, cells exhibited a G1 phase arrest. Although this cell phenotype was different from WSPM10 and WSPM2.5 exposure groups. However, it also indicated that the expression of RPL13, RPL6 and RPL18A genes are associated with cell cycle of A549 cells. The mRNA levels of RPL13 and RPL18A in A549 cells were downregulated during WSPM exposure, which was consistent with previous identification results by mass spectrometry. This indicated that when the expression of RPL13 and RPL18A is disrupted, the A549 cell cycle is affected. Although there have been no reported the regulatory mechanisms of RPL13 and RPL18A on the cell cycle. Some RPs have been found to increase intracellular stability of $\mathrm{p} 53$ by direct interacting with MDM2, thereby affecting cell proliferation, cell cycle, and apoptosis, including RPL11 [34], RPL5 [35], RPL23 [36], RPS7 [37], RPS2 [38], RPL13 [39] and RPS25 [29]. This mechanism is also known as "nucleolar stress-MdM2-p53 signaling pathway "[40]. The exposure of Act D induced ribosomal stress. The p53 level sharply increased, and p21, a downstream gene of p53, shown the same increasing pattern as p53. We treated A549 cell with WSPM10 or WSPM2.5 for $24 \mathrm{~h}$, the expression of ATM and p53 both increased in transcription and translation level. The mRNA level of MDM2 increased, and its protein level hardly changed as Act D exposure group. The protein level of p21 increased a small amount in the WSPM10 $(100 \mu \mathrm{g} / \mathrm{ml})$ or WSPM2.5 $(200 \mu \mathrm{g} / \mathrm{ml})$ exposure group, but its increase was not dose-dependent. The results show that WSPM blocked A549 cells in the G2/M phase by activating the ATMp53-p21 signaling pathways, and this effect may be related to RPs. Liu et al. found that $\mathrm{NaF}$ induced cell cycle arrest by activating the ATM-p53-p21 on hepatocellular cell cycle progression in mice [41].

On the other hand, for the classical RB cell cycle regulation pathway, the activation of the cyclinD-CDK4/ CDK6 kinase complex phosphorylates $\mathrm{RB}$ and promotes the release of $E_{2} F_{1}$ [42]. The protein level of CDK4, RB1, $\mathrm{E}_{2} \mathrm{~F}_{1}$, and CDK 2 increased in the WSPM10 or WSPM2.5 exposure group. Among them, only the mRNA level of $R B 1$ significantly upregulated in both case of exposure, and the others upregulated in only one case of exposure. Compared with the NC group, when RPL13 or RPL18A gene expression was inhibited, the mRNA level of $R b 1$ significantly increased, while $E_{2} F_{1}$ mRNA expression significantly decreased. It may be due to $\mathrm{Rb}$ pathway activation, a large amount of $\mathrm{E}_{2} \mathrm{~F}_{1}$ was released in vivo, and there was excessive intracellular $\mathrm{E}_{2} \mathrm{~F}_{1}$, leading to the activation of a related negative feedback mechanism, inhibiting the expression of the $E_{2} F_{1}$ gene [43]. The mRNA level of TP53 was no significant change in RPL13-knockdown cells and this increased by nearly $20 \%$ in RPL18A-knockdown cells. There results indicate that $\mathrm{G1}$ phase arrest may be induced through $\mathrm{Rb} / \mathrm{E}_{2} \mathrm{~F}_{1}$ pathway in RPL13-knockdown cells, rather than a p53dependent manner. This arrest effect of G1 phase may be associated with both the $\mathrm{p} 53$ and $\mathrm{Rb} / \mathrm{E}_{2} \mathrm{~F}_{1}$ pathways in RPL18A-knockdown cells. There results shown that WSPM also induced A549 cell cycle arrest by activating $\mathrm{Rb} / \mathrm{E}_{2} \mathrm{~F}_{1}$ signaling pathways, and this effect also may be related to RPs.

WSPM chemical analysis revealed that $\mathrm{La}^{3+}, \mathrm{Ce}^{3+}$, $\mathrm{Nd}^{3+}$ and $\mathrm{F}^{-}$were present in both WSPM2.5 and WSPM10. Furthermore, $2 \mathrm{mM} \mathrm{NaF}$ or $\mathrm{CeCl}_{3}$ induced A549 cells $\mathrm{S}$ phase arrest, but not significantly change $(P>0.05)$ in the $\mathrm{LaCl}_{3}$ or $\mathrm{NdCl}_{3}$ exposure group at the same doses. In addition, G2/M phase arrest was induced in the $\mathrm{NaF}$ exposed group, and this cell cycle phenotype was similar to that in the WSPM10 or WSPM2.5 
exposure groups. Furthermore, this also suggests that $\mathrm{LaCl}_{3}, \mathrm{NdCl}_{3}, \mathrm{NaF}$ and $\mathrm{CeCl}_{3}$ may affect cell growth through different pathways. Fluorides have been shown to inhibit proliferation and induced apoptosis in epithelial lung cells from human and rats by activation of MAP kinase p38 and possibly JNK. In in vitro experiments on other cells, inhibition of protein synthesis and cell-cycle progression, alterations in cellular metabolism [3], and induction of inflammatory cytokine release [44] have been observed. Our results also showed that fluoride inhibited cell proliferation and cell cycle progression in A549 cells. In addition, fluoride is beneficial to cell proliferation by activation of ERK pathway in bone cells [44]. The activation of ERK by fluoride in the A549 cells is associated with the cell proliferation. This also suggests that fluoride may be both stimulatory proliferation signal and growth inhibitory signal in the lung cell [1]. $\mathrm{CeCl}_{3}$ inhibited human lung cancer cells PG cells (PG cells) proliferation and induced cell cycle arrest at the G1 phase. But it had no effect on human gastric carcinoma cells BGC823 and human diploid fibroblasts 2BS at the same concentration [45]. Lanthanum citrate has the same effect as $\mathrm{CeCl}_{3}$ for PG cells [46]. In addition, exposure to $\mathrm{La}$ (III) induced oxidative stress,activation of $\mathrm{Ca}^{2+}$ ATPase activity and inhibition of catalase, superoxide dismutase and glutathione peroxidase activity in the rats' hippocampal cells [47]. The cytotoxicity of REE is influenced by the nature and concentration of REE, exposure time and cell types. It was found that mRNA expression changes of cell cycle regulators in the $\mathrm{NaF}$ and $\mathrm{CeCl}_{3}$ were highly consistent with those in the WSPM2.5 or WSPM10 exposure groups, including $M D M 2, R B 1, A T M$, TP53, $C D K 2$, and $C D K 4$ genes. In the NaF exposure groups, the levels of transcription and translation of p53, MDM2, and p21 were inconsistent, but ATM, RB1 and $E_{2} F_{1}$ both were upregulated. It indicated that $\mathrm{NaF}$ may affect A549 cell proliferation and cell cycle by $\mathrm{RB} 1-\mathrm{E}_{2} \mathrm{~F}_{1}$ pathway. Furthermore, the expression of $\mathrm{p} 21, \mathrm{p} 53, \mathrm{E}_{2} \mathrm{~F}_{1}, \mathrm{RB} 1$ shown consistent translation level with transcription level in the $\mathrm{LaCl}_{3}$ and $\mathrm{CeCl}_{3}$ exposure groups. Besides RB1- $\mathrm{E}_{2} \mathrm{~F}_{1}$ pathway, $\mathrm{LaCl}_{3}$ or $\mathrm{CeCl}_{3}$ may be induce $\mathrm{A} 549$ cells arrest by p53-MDM2-p21 pathway. Thus, it can be speculated that WSPM induced A549 cell cycle disorder through $\mathrm{La}^{3+}$, $\mathrm{Ce}^{3+}$, and $\mathrm{F}^{-}$. Different chemical components may be some differences in the mechanisms of action for A549 cell cycle [42]. Because of the difference in composition, WSPM2.5 and WSPM10 also differed with regard to the effects on the expression of cell cycle regulator.

In addition, The expression of TLR4 upregulated in the $\mathrm{CeCl}_{3}, \mathrm{NaF}$ and WSPM2.5 exposure groups, and increased by 27.28 times $(P<0.01), 8.73$ times $(P<0.01)$, and 2.96 times $(P<0.05)$, respectively, suggesting that TLR4 receptors may be play a role in the cell perception for these external stimuli [48].
The protein levels of caspase 3, 6, 8 and 9 were inhibited by low levels of WSPM10 or WSPM2.5 $(<100 \mu \mathrm{g} /$ $\mathrm{ml}$ ), and exposed cells try to repair the mechanism to response with the external stimulation caused by the injury. Then, when the dose was more than $100 \mu \mathrm{g} / \mathrm{ml}$, intracellular caspase 3 increased, which is the quantity of the cell debris flow diagram, indicating that cell apoptosis may have started the program. In addition, it was found that in the process of WSPM exposure, the expression of NF- $\mathrm{kB}$ has no significant change $(P>0.05)$, and the MYD88 gene expression also did not exhibit obvious changes. Therefore, it can be concluded that the high dose of $200 \mu \mathrm{g} / \mathrm{ml}$ of WSPM, and not the NF- $\mathrm{kB} /$ MYD88 pathway, induced the apoptosis of A549 cells in the process. Furthermore, the expression of caspase 3 may be related to the increase in caspase 8 and 9 , but there is no direct correlation.

Our study is the first to show a correlation between WSPM of Bayan Obo rare earth mining and A549 cell cycle, but some limitations should be considered. First, A549 cells is a widely used cell line in the field of cytotoxicity of atmospheric particulates, is not equivalent in sensitivity and response to human primary cell lines. However, A549 cells contained wild-type (wt) p53. Therefore, A549 cells has some value in the study of p53-mediated cell cycle regulation. Second, doses of WSPM are extremely high doses in our study, but in fact, WSPM is generally a small fraction of the total PM. It is not known whether there is a difference in the cell cycle effects between long-term low-dose and shortterm high-dose exposure. Finally, the effect of cytotoxicity of $\mathrm{F}^{-}, \mathrm{Ce}^{3+}$ and $\mathrm{La}^{3+}$ on the A549 cells were studied in our study. A single component in WSPM can not completely represent toxic effect of WSPM. Some synergetic or antagonistic effects may exist between two or more components. Despite these limitations, the identification of the effects and potential mechanism between WSPM and cell cycle is a new step toward a better understanding of the correlation between atmospheric particulates and human health risks in Bayan Obo rare earth mining.

\section{Conclusions}

In the process of investigating the toxicity mechanism of APM, many difficulties were encountered, and this was mainly because APM is a complex mixture of particles with complex physical and chemical properties, and its composition has certain regional and seasonal characteristics, making its toxicity mechanism often have some particularity. A toxicity analysis was conducted on the water-soluble fraction of APM in the Bayan Obo mining area. The toxic effects of WSPM on A549 cells is mainly manifested in inhibition of cell proliferation and ribosomal proteins biosynthesis, and DNA damage (Figure 
S11). In addition, $\mathrm{La}^{3+}, \mathrm{Ce}^{3+}$, and $\mathrm{F}^{-}$were likely to be the main toxic substances in WSPM. Together with rare earth elements, such as $\mathrm{Ce}^{3+}$ and $\mathrm{La}^{3+}$, it affects the expression of $M D M 2, R B 1, A T M, T P 53, p 21$ and $E_{2} F_{1}$ genes, thereby affecting the A549 cell cycle (Figure S12). However, many details still needs to be added through follow-up work. For example, determining whether there is any synergistic effect between different components in WSPM during this process, and determining how WSPM affects the reduction of ribosomal protein expression. The investigators consider that the answers to these questions can provide a scientific basis for the local response to atmospheric particulate pollution, and the protection of public health.

\section{Methods}

\section{Collection and characterization of atmospheric particulates}

The quartz fiber filters $(90 \mathrm{~mm} \varnothing, 2 \mu \mathrm{m}$; Whatman, GE life science, UK) were employed for sampling by a middle volume sampler (Model TH-150, TianHong, Wuhan, China) at a flow rate of $100 \mathrm{~L} \cdot \mathrm{min}^{-1}$. Different particle size cutters were used to collect atmospheric PM2.5 and PM10 samples respectively. The collection of every filter lasted for $24 \mathrm{~h}$ (from 8:00 a.m. to 8:00 a.m. the following day). Airborne PM10 and PM2.5 were collected from the residential area of the Bayan Obo mining district $\left(41^{\circ} 47^{\prime} \mathrm{N}, 109^{\circ} 58^{\prime} \mathrm{E}\right)$, which is located at one kilometer south of the mine region in Baotou, an industrial city in northern China. 2 sampling points were set up in the mining area, $1000 \mathrm{~m}$ below the wind direction of the mining area. Each sampling point was equipped with 3 air samplers, one for $\mathrm{PM}_{10}$ collection, one for $\mathrm{PM}_{2.5}$ and the other for standby. When a failure happens on one sampler, then this standby sampler was able to continue sampling. For wind conditions, the prevailing wind direction was northwest, and the average wind speed was $3 \mathrm{~m} / \mathrm{s}$. The samplers were set on the rooftop, which was approximately $5.0 \mathrm{~m}$ above the ground from January to April in 2015.

After the sampling, these filters were carefully removed from the sampler, placed in a plastic container, and preserved in darkness at $-4^{\circ} \mathrm{C}$ until particle extraction or chemical characterization was performed.

\section{Particle extraction}

After gravimetric analysis, The quartz fiber filter were cut into square pieces of $1.0 \mathrm{~cm} \times 1.0 \mathrm{~cm}$ and placed in ultrapure water (Millipore, resistivity not less than 18.2 $\mathrm{M} \Omega \mathrm{cm}^{-1}$ at $25{ }^{\circ} \mathrm{C}$ ), which was fully mixed. Ultrasonic treatment was performed at room temperature (Shumei Instrument, KQ-700 V, Kunshan, China) for $30 \mathrm{~min}$. Multilayer sterile gauze was used for filtration, and the insoluble substance was rinsed with ultrapure water for
3 times. The filtrate was mixed and prepared into powder by vacuum freeze-drying apparatus (Sihuan Scientific Instrument, LGJ-100 F, Beijing, China). The weights of the water-soluble fractions were obtained and its proportion in PM2.5 or PM10 were calculated. The detached particles were resuspended in sterilized normal saline to obtain aliquots at a final concentration of $2 \mathrm{mg} / \mathrm{ml}$, and these were stored at $-80^{\circ} \mathrm{C}$ for use.

The chemical constituents of the samples were determined using inductively coupled plasma-atomic emission spectrometry (ICP-AES; SPECTRO ARCOSII $\mathrm{GmbH}$ Boschstr, Kleve, Germany) and ion chromatography (Dionex IC900; Thermo Fisher Scientific, USA) .

\section{Cell culture and WSPM treatment}

Human lung epithelial cells A549 (Fuheng Biology Inc., Shanghai, China) were routinely maintained in RPMI1640 medium at $\mathrm{pH} 7.2$, supplemented with $10 \%$ fetal bovine serum (FBS; Thermo Fisher Scientific, Gibco, USA) and $1 \%$ penicillin/streptomycin (Thermo Fisher Scientific, Gibco, USA), and maintained in a humidified $5 \% \mathrm{CO}_{2}$ incubator at $37{ }^{\circ} \mathrm{C}$. A549 cells were cultured for $24 \mathrm{~h}$ in 96 -well plates at a density of $5 \times 10^{4}$ cells per well. The working solutions of WSPM were prepared by diluting the stock solution in culture medium. A549 cells were treated with WSPM at the final concentration of 0 , $12.5,25,50,100$ or $200 \mu \mathrm{g} / \mathrm{ml}$ for $6,24,48$ or $72 \mathrm{~h}$, respectively, or treated with actinomycin D $(5 \mathrm{nM})$ for $24 \mathrm{~h}$. Meanwhile, the normal culture medium was set as the control group.

\section{MTT assay}

After treatment with WSPM, these cells were washed and treated with $20 \mu \mathrm{l} \mathrm{of} 5 \mathrm{mg} / \mathrm{ml}$ of 3-(4,5-dimethylthiazol-2-yl)-2,5-diphenyl tetrazolium bromide (MTT, Sigma-Aldrich, MO, USA) to determine the cell viability. After formazan formation by MTT, $150 \mu \mathrm{l}$ of dimethyl sulfoxide (DMSO; Sigma-Aldrich, MO, USA) was added with oscillation for $10 \mathrm{~min}$. Optical density (OD) was measured at $490 \mathrm{~nm}$ using a microplate reader (Thermo Scientific, PA, USA). Cell inhibitory rate $=[1-(\mathrm{OD}$ experiments - OD blank) / (OD control - OD blank)] $\times$ $100 \%$. The experiments for control and exposure groups were each performed in triplicate.

\section{Flow cytometric cell cycle}

Cells were treated with WSPM10 after $10^{6}$ cells were placed in 6-well plates at $37{ }^{\circ} \mathrm{C}$ with $5 \% \mathrm{CO}_{2}$ for $24 \mathrm{~h}$. Cells were detached by trypsinization, and collected and fixed in $5 \mathrm{ml}$ of $75 \%$ cold ethanol at $4{ }^{\circ} \mathrm{C}$ for two hours. Then, these cells were incubated with $0.5 \mathrm{ml}$ of propidium iodide (PI; Sigma Aldrich, MO, USA) at $37{ }^{\circ} \mathrm{C}$ for 30 min. DNA content was detected using a flow cytometer (ACEA, NovoCyte, USA). 


\section{Protein extraction and digestion}

After treatment, the A549 cells were washed for three times with cold PBS, and scraped and centrifuged at 1 , $500 \mathrm{~g}$ for three minutes. Then, the resulting pellets were homogenized in $0.55 \mathrm{ml}$ of lysis buffer $(30 \mathrm{mM}$ of HEPE $\mathrm{S}, 8 \mathrm{M}$ of urea, $1 \mathrm{mM}$ of PMSF, $2 \mathrm{mM}$ of EDTA and 10 $\mathrm{mM}$ of DTT), vortexed for one minute, sonicated for five minutes, and unlysed debris by centrifugation at 20 , $000 \mathrm{~g}$ for $30 \mathrm{~min}$. Afterwards, the protein was reduced (10 mM of DTT, $56{ }^{\circ} \mathrm{C}$, one hour), alkyated ( $55 \mathrm{mM}$ of iodoacetamide, $37{ }^{\circ} \mathrm{C}$, two hours) and precipitated with the addition of 4 volumes of cold acetone $\left(-20{ }^{\circ} \mathrm{C}\right.$, three hours). Next, the protein was collected by centrifugation $\left(20,000 \mathrm{~g}, 4{ }^{\circ} \mathrm{C}, 30 \mathrm{~min}\right)$, and the precipitates were redissolved in $0.30 \mathrm{ml}$ of buffer ( $50 \%$ TEAB, $0.1 \%$ SDS), sonicated [49] for three minutes, centrifuged $\left(20,000 \mathrm{~g}, 4{ }^{\circ} \mathrm{C}\right.$, $30 \mathrm{~min}$ ), and frozen at $-80^{\circ} \mathrm{C}$. The protein concentration of the supernatant was measured using the Bradford assay. For each sample, $100 \mu \mathrm{g}$ of protein was resuspended in digestion buffer (50\% TEAB, $0.1 \% \mathrm{w} / \mathrm{v}$ SDS). Then, equal aliquots of $100 \mu \mathrm{g}$ from each lysate were digested with $3 \mu \mathrm{l}$ of $1 \mu \mathrm{g} / \mu \mathrm{l}$ of trypsin for $24 \mathrm{~h}$ at $37{ }^{\circ} \mathrm{C}$, and lyophilized. Afterwards, $30 \mu \mathrm{l}$ of $50 \%$ TEAB was added into each sample tube.

\section{Labeling with the ITRAQ 8-plex reagent}

Labeling solutions were provided by the iTRAQ 8-plex reagent kits (Applied Biosystem, Carlsbad, CA, USA). According to manufacturer protocol, the fresh vial of iTRAQ reagent 8-plex was required to reach room temperature. Then, $70 \mu \mathrm{l}$ of isopropanol were added to each reagent vial, and vortex-mixed for one minute. Afterwards, the peptides were labeled with the iTRAQ label reagent, and 8-plex labeling was performed for two hours at room temperature. All labeled peptides, in which the quantity was determined from each tag, were combined in one tube. Finally, the pooled peptides were dried under vacuum [50-52].

\section{Cation exchange chromatography}

The combined peptide mixture was separated using a strong cation exchange column (Phenomenex, Luna 'SCX, $4.6 \times 250$ mm, $5 \mu \mathrm{m}, 100 \AA \AA$; Torrance, California, USA). The labeled peptides were solubilized with $1 \mathrm{ml}$ of loading buffer $(25 \% \mathrm{v} / \mathrm{v}$ acetonitrile, $10 \mathrm{mM}$ of $\mathrm{KH}_{2} \mathrm{PO}_{4}, \mathrm{pH} 3.0$ with phosphoric acid) and centrifuged $\left(15,000 \mathrm{~g}, 4{ }^{\circ} \mathrm{C}, 10 \mathrm{~min}\right)$. Then, the supernatant was loaded and washed isocratically for $40 \mathrm{~min}$ at $0.5 \mathrm{ml} /$ $\mathrm{min}$ to remove the excess reagent. The samples were eluted with a gradient of $0-2 \mathrm{M} \mathrm{KCl}(25 \% \mathrm{v} / \mathrm{v}$ acetonitrile, $10 \mathrm{mM}$ of $\mathrm{KH}_{2} \mathrm{PO}_{4}$, $\mathrm{pH} 3.0$ with phosphoric acid) over $36 \mathrm{~min}$ at $1.0 \mathrm{ml} / \mathrm{min}$, with fractions collected at one minute intervals.

\section{Peptide desalination}

Individual SCX fractions were desalted using solid-phase extraction cartridges (Phenomenex Strata-X cartridge, 3 $\mathrm{ml}$ and $60 \mathrm{mg}$; Torrance, California, USA). The Strata-X cartridge were washed with $1 \mathrm{ml}$ of methanol and $1 \mathrm{ml}$ of water prior to use, and were equilibrated with $5 \%$ acetonitrile. Then, the sample was solubilized in $1 \mathrm{ml}$ of ultrapure water, loaded onto the Strata-X cartridge, and desalted with $1 \mathrm{ml}$ of $5 \%$ acetonitrile. The peptides were eluted using $1 \mathrm{ml}$ of acetonitrile from the column, and the solvent was removed by vacuum drier under $4{ }^{\circ} \mathrm{C}$.

\section{LC-MS analysis}

The desalted peptide mixture was redissolved with $0.1 \%$ formic acid (FA). Peptide separation was performed on a nano-chromatography system (Ultimate ${ }^{\text {ma }} 3000$, Thermo Fisher Scientific, USA). The sample was injected and captured onto a C18 column (Acclaim $^{\mathrm{nu}}$ PepMap $^{\mathrm{Tw}}$, $75 \mu \mathrm{m} \times 2 \mathrm{~cm}, 3 \mu \mathrm{m}, 100$; Thermo Fisher Scientific, USA) and eluted onto a C18 analytical column $(75 \mu \mathrm{m} \times$ $10 \mathrm{~cm}, 5 \mu \mathrm{m}, 300$, Agela Technologies, China). The peptides were eluted using an automated gradient from $95 \%(\mathrm{v} / \mathrm{v})$ buffer A (0.1\% FA in water) to $80 \%(\mathrm{v} / \mathrm{v})$ buffer B (0.1\% FA in acetonitrile) over $48 \mathrm{~min}$ at a flow rate of $400 \mathrm{nl} \cdot \mathrm{min}^{-1}$.

The eluted peptides from the C18 column were directly entered to the Q-Exactive MS (Thermo Fisher Scientific, Waltham, MA, USA) through a capillary tip for electrospray, which was set in positive ion mode. The electrospray voltage was $1.8 \mathrm{kV}$, and the capillary temperature was $320{ }^{\circ} \mathrm{C}$. For each run, $1 \mu \mathrm{l}$ of sample was loaded, and each sample was analyzed in duplicate. Full MS scans were acquired in the Orbitrap mass analyzer within $350-2000 \mathrm{~m} / \mathrm{z}$, with a full scan resolution of $70,000(\mathrm{~m} / \mathrm{z} 200)$ and an MS/MS scan resolution of $17,500(\mathrm{~m} / \mathrm{z} 200)$. The MS/MS scan had a minimum signal threshold of $1 \times 10^{5}$, and an isolation width of $2 \mathrm{Da}$. In order to evaluate the performance of the mass spectrometry on the iTRAQ labeled samples, higher collision energy dissociation (HCD) was employed. In order to optimize the MS/MS acquisition efficiency of HCD, normalized collision energy (NCE) was systemically examined at 28 , stepped $20 \%$. The MS survey spectrum was measured.

\section{Peptide and protein identification}

All .raw files were converted to MGF format using Proteome Discoverer 1.3/1.4 (Thermo Fisher Scientific, Waltham, MA). MASCOT 2.3.01 (Matrix Science, Boston, MA, USA) was used for the database search against the Uniprot human database (updated on 15/03/2016, 20,199 sequences). The corresponding reversed sequences were also appended to the database for estimating the false discovery rate (FDR) of the peptide 
identification. The database search parameters included up to one missed cleavages allowed for full tryptic digestion, a mass tolerance of $15 \mathrm{ppm}$ for the precursor, and a mass tolerance of $20 \mathrm{mmu}$ for fragment ions. For all experiments, the carbamidomethylation of cysteine residues was set as a fixed modification, while methionine oxidation, and $\mathrm{N}$-terminal acetylation of protein and iTRAQ modification of peptide $\mathrm{N}$ termini were set as variable modifications.

The result from each run indicated less than $1 \%$ FDR for peptide identification. For identifications where multiple peptides met these criteria, the results indicated a less than $0.1 \%$ FDR. On the protein level, there was a minimum number of peptide 1 for each protein, in which only rank 1 peptides were counted, and peptides only counted in top scored proteins were applied for all data filtration. In addition, protein grouping was enabled, and a strict maximum parsimony principle was applied. Therefore, if multiple proteins were identified from same peptides, these proteins were grouped into one protein group, and each protein group has at least one unique peptide. The protein groups and peptides identified by UHPLC ESI-MS/MS analysis from A549 cell lysate digest with the MASCOT database search are listed in the supporting material.

The protein quantification settings were as follows: protein ratio type of 'median', normalization method of the 'median', outlier removal of 'automatic', minimum peptide threshold of ' 1 ', a $95 \%$ confidence interval $(P<$ 0.05 ) to assess the accuracy of the protein ratio, and a minimum of three spectra for quantifying a protein. The iTRAQ ratios were normalized to the control group.

\section{Bioinformatics analysis of proteomics data}

The identified proteins were classified according to the annotations obtained from the UniProt knowledgebase. OmicsBean (http://www.omicsbean.cn) was utilized to analyze the GO distribution of the obtained differential proteins. The distributions of each protein in the biological process (BP), cellular components (CCs) and molecular functions (MF) were based on the Gene Ontology (GO) categories. A Kyoto Encyclopedia of Genes and Genomes (KEGG) pathway analysis (http:// www.genome.ad.jpkegg/pathway.html) was performed to enrich the high-level functions in the defined biological systems.

\section{Verification of DEPs}

\section{Multiple reaction monitoring (MRM) analysis}

For each differentially expressed protein in the iTRAQ data, one unique tryptic peptide of length of 6-20 amino acids were chosen for the MRM. Peptides were excluded when they had a missed cleavage, had potential ragged ends, or contained amino acids that were susceptible to variable modifications, including cysteine and methionine. Precursor ions were monitored for confident identification of the peptides. Candidates for control proteins were identified from iTRAQ, according to the following criteria: if they had a fold change of $1 \pm 0.2$, the coefficient of variation (CV) was $<10 \%$ in the iTRAQ data. Next, the samples were trypsin digested. For the supernatant samples, strong cation exchange was performed using SCX tips (Thermo Fisher Scientific) after digestion. The MRM assays were carried out using a QTRAP 6500 mass spectrometer (AB SCIEX, CA, USA) coupled to an ekspert NanoLC 425 system (Ekspert Technologies, USA). The mobile phases consisted of solvent $\mathrm{A}$, $2 \%$ acetonitrile with $0.1 \%$ FA and solvent B, and $98 \%$ acetonitrile with $0.1 \%$ FA. Each sample was loaded onto a NanoLC trap column (ChromXP 18CL, $350 \mu \mathrm{m} \times 0.5$ $\mathrm{mm}, 3 \mu \mathrm{m}, 120$ Å; Ekspert Technologies, USA). The peptides were separated using a NanoLC column (ChromXP C18, $75 \mu \mathrm{m} \times 15 \mathrm{~cm}, 5 \mu \mathrm{m}, 120 \AA$, Ekspert Technologies, USA) at $0.3 \mu \mathrm{l} \cdot \mathrm{min}^{-1}$, with a linear gradient of $5-45 \%$ solvent B for $48 \mathrm{~min}$ and $80 \%$ solvent B for five minutes. The MS parameters were set, as follows: positive ionization, high sensitivity mode, ion source gas 1 (GS1) at 15.00 , ion source gas 2 (GS2) at 0.00 , curtain gas (CUR) at 35.00 , ionspray voltage floating (ISVF) at $2,400.00 \mathrm{~V}$, interface heater temperature (IHT) at $150.00{ }^{\circ} \mathrm{C}$, Q1 and Q3 at unit resolution, scan speed at $10 \mathrm{Da} / \mathrm{s}$, collision gas (CAD) at high, entrance potential (EP) at 10, and collision cell exit potential (CXP) at 10 .

\section{Western blot analysis}

Cells were collected in RIPA lysis buffer, and the proteins were quantified using a BCA Protein Concentration Assay Kit (MDL Biotechnology, China). The protein was isolated on a $10 \%$ SDS-PAGE gel (MDL Biotechnology, China), and transferred onto PVDF membranes. Then, the membranes were blocked with $5 \%(\mathrm{w} / \mathrm{v})$ nonfat dry milk in PBS and $0.05 \%$ Tween. The primary antibodies used as follows: anti-FAK antibody (1:1,000; MDL Biotechnology, China), anti-CDC27 antibody (1:1,000; MDL Biotechnology, China), RPRD1A-antibody (1:1,000; MDL Biotechnology, China), RPL34-antibody (1:1,000; MDL Biotechnology, China), RPL24-antibody (1:1,000; MDL Biotechnology, China), EIF6-antibody (1:1,000; MDL Biotechnology, China), p53-antibody (1:1000; Affinity, USA), MDM2-antibody (1:1000; Abcam, USA), p21-antibody (1:1000; Epitmics, USA), CDK2-antibody (1:3000; Abcam, USA), CDK4-antibody (1:3000; Abcam, USA), RB-antibody (1:2000; Abcam, USA), ATMantibody (1:3000; Abcam, USA), $\mathrm{E}_{2} \mathrm{~F}_{1}$-antibody (1:1000; Abcam, USA). $\beta$-actin (1:1000; MDL Biotechnology, China) or GAPDH (1:5000; Abcam, USA) was used as the loading control. The secondary antibodies were incubated with goat IgG-HRP (1:5,000; MDL Biotechnology, 
China) at room temperature for one hour. The blots were detected using a ChemiDoc MP chemiluminescence imaging system (Bio-rad, USA).

\section{Small interfering RNA}

Based on the gene sequence in GenBank and siRNA design principles, the siRNA sequences were designed and chemically synthesized by Shanghai Shenggong Biotech. The constructs are listed in Table S1. The cell blank, negative control and interference groups were set-up. Cells in the exponential growth period were inoculated into the cell culture plate at a certain concentration for $24 \mathrm{~h}$, and the transfection cell density reached $50-70 \%$. The siRNA oligonucleotides were transfected into A549 cells using the lipofectamine 3000 (Thermo Fisher, USA), according to manufacturer's instructions. The transfection efficiency was detected by fluorescent labeled Cy3-siRNA.

\section{RNA isolation and quantitative real-time PCR assay}

A549 cells were seeded in 6-well plates at a density of approximately $1 \times 10^{6}$ cells per well. Then, these cells were exposed to WSPM, $\mathrm{LaCl}_{3}, \mathrm{CeCl}_{3}, \mathrm{NdCl}_{3}$ and $\mathrm{NaF}$, respectively, for $24 \mathrm{~h}$. Subsequently, these cells were trypsinized and collected. Afterwards, the adherent cells were collected. The total RNA was extracted using the TRIzol reagent (Invitrogen, USA), according to manufacturer's instructions.

The total RNA of A549 cells was extracted using a TRI$\mathrm{zol}^{\mathrm{TM}}$ RNA reagent (InvitroGen, USA), according to manufacturer's protocol. The mRNA levels for modulated genes were determined by the reverse transcription of total RNA, followed by qRT-PCR, on a LightCycler 480 realtime PCR (Roche, Germany) using PrimeScript reverse transcription reagent kits (Takara, Japan), according to manufacturer's protocol. The primers were designed for the modulated genes. These are presented in Supplemental Table S2. All experiments were performed in triplicate.

\section{Enzyme-linked immunosorbent assay (ELISA)}

The levels of related cytokines in A549 cells were measured using the Human Caspase 3, 6, 8 and 9 ELISA Kit (MDL Sciences, China), according to manufacturer's instructions. Each sample was assayed in triplicate.

\section{Statistical analysis}

The data (except for the fold change of protein expression) were all expressed as the mean \pm standard deviation (SD) of triplicate experiments. Significant differences among multiple groups were determined using one-way analysis of variance (ANOVA), followed by the least significant difference post hoc test. Probabilities of $P<0.05$ were considered statistically significant.

\section{Abbreviations}

WSPM10: Water soluble particulate matter 10; WSPM2.5: Water soluble particulate matter 2.5; WSPM: The general term for WSPM10 and WSPM2.5; APM: Atmospheric particulate matter; REE: Rare earth elements;

ITRAQ: Isobaric tags for relative and absolute quantification; IC: Ion Chromatography; ICP-AES: Inductively Coupled Plasma-Atomic Emission Spectroscopy; qRT-PCR: Quantitative real time polymerase chain reaction; MRM: Multiple reaction monitoring; MTT: 3-(4,5-dimethyl-2-thiazolyl)-2,5diphenyl-2-H-tetrazolium bromide; DMSO: Dimethyl sulfoxide; ELISA: Enzyme linked immunosorbent assay; RPL: 605 ribosomal protein; RPS: 40 S ribosomal protein; TLRs: Toll-like receptors; GO: Gene Ontology; KEGG: Kyoto Encyclopedia of Genes and Genomes; NC: Negative control; LPS: Lipopolysaccharides; DEP: Diesel Exhaust Particles; LDH: Lactate dehydrogenase; OD: Optical density; Pl: Propidium iodide; FC: Fold Change; FDR: False discovery rate; LC-MS/MS: Liquid chromatography-tandem mass spectrometry; siRNA: Small interfering RNA; WB: Western blot; SDS-

PAGE: Sodium dodecyl sulfate-polyacrylamide gel electrophoresis

\section{Supplementary Information}

The online version contains supplementary material available at https://doi. org/10.1186/s12989-021-00416-Z

Additional file 1:

\section{Acknowledgements}

The present study was supported by the National Natural Science

Foundation of China (Grant nos. 81473017 and 31460249).

Authors' contributions

Conceived and designed the experiments: Juan Sun, Xulong Zhang and Yuan Xia. Relevant design in respiratory: Dejun Sun Performed the experiments: Yuan Xia and Xiaoe Zhang. Analyzed the data: Qingjun Cai and Qihao Wang. Contributed the reagents/materials/analysis tools: Li

Wang. Approved the final version: Yuan Xia, Juan Sun, and Yumin Gao.

\section{Funding}

The present study was supported by the National Natural Science Foundation of China (Grant nos. 81473017 and 31460249).

Availability of data and materials

The datasets used and/or analysed during the current study are available from the corresponding author on reasonable request.

\section{Declarations}

Ethics approval and consent to participate

Not applicable.

Consent for publication

Not applicable.

\section{Competing interests}

The authors declare that they have no competing interests.

\section{Author details}

${ }^{1}$ School of Public Health, Inner Mongolia Autonomous Region, Jinshan Economic and Technological Development Zone, Inner Mongolia Medical University, Inner Mongolia Autonomous Region 010010 Hohhot, China. ${ }^{2}$ Department of Immunology, School of Basic Medical Sciences, Capital Medical University, Beijing, China. ${ }^{3}$ Inner Mongolia People's Hospital, Inner Mongolia Autonomous Region, Hohhot, China.

Received: 7 August 2019 Accepted: 2 June 2021

Published online: 02 August 2021

References

1. World Health Organization $(\mathrm{WHO})$. Health effects of particulate matter. Policy implications for countries in eastern Europe, Caucasus and central Asia. Copenhagen:WHO Regional Office for Europe; 2013 [http://www.euro. 
who.int/_data/assets/pdf_file/0006/189051/Health-effects-of-particulate-ma tter-final-Eng.pdf, accessed 27 August 2013].

2. Kim KH, Kabir E, Kabir S. A review on the human health impact of airborne particulate matter. Environ Int. 2015;74:136-43.

3. Thompson JE. Airborne Particulate Matter Human Exposure and Health Effects. J Occup Environ Med. 2018;60(5):392-423.

4. Tositti L. Physical and Chemical Properties of Airborne Particulate Matter. In: Capello F, Gaddi A, editors. Clinical Handbook of Air Pollution-Related Diseases. Cham: Springer; 2018. pp. 7-32.

5. Tong YL, Li KX, Tian SH, et al. Seasonal variation of rare earth element concentrations in PM10 and their cytotoxicity in a typical rare earth mining city [J]. Asian J Ecotox. 2017;12(5):129-40. (in Chinese).

6. Li K, Liang T, Wang LQ, Yang ZP. Contamination and health risk assessment of heavy metals in road dust in Bayan Obo Mining Region in Inner Mongolia, North China. J Geogr Sci. 2015;25(12):1439-51.(in Chinese).

7. Schmitz-Spanke S, Rettenmeier AW. Protein expression profiling in chemical carcinogenesis: A proteomic-based approach. Proteomics. 2011;11:644-56.

8. Huang QY, Zhang J, Peng SY, Tian MP, Chen JS, Shen HQ. Effects of water soluble PM2.5 extracts exposure on human lung epithelial cells (A549): A proteomic study. J Appl Toxicol. 2014;34:675-87.

9. Zhou X, Liao WJ, Liao JM, Liao P, Lu H. Ribosomal proteins: functions beyond the ribosome. J Mol Cell Biol. 2015;7(2):92-104.

10. Gao Z, Zhou Q. Contamination from rare earth ore strip mining and its impacts on resources and eco-environment. J Eco. 2011;30(12):2915-22.

11. Guo W, Fu R, Zhao R, et al. Distribution Characteristic and Current Situation of Soil Rare Earth Contamination in the Bayan Obo Mining Area and Baotou Tailing Reservoir in Inner Mongolia. Environ Sci. 2013;34(5):1895-900. (in Chinese).

12. Wang W, Tao H, Kim D, et al. Rare Earth Element Components in Atmospheric Particulates during Sand-Dust Weather in Baotou. J Environ Hyg. 2012;2(6):257-61

13. Guo PR, Jia XY, Duan TC, et al. Speciation Analysis of Rare Earth Elements in Soil. Chin J Anal Chem. 2008;36(11):1483-7.(in Chinese).

14. Ma H, Li J, Wan C, Liang Y, Zhang X, Dong G, et al. Inflammation response of water-soluble fractions in atmospheric fine particulates: a seasonal observation in 10 large chinese cities. Environ Sci Technol. 2019;53(7):3782-90.

15. Naimabadi A, Ghadiri A, Idani E, et al. Chemical composition of PM10 and its invitro toxicological impacts on lung cells during the Middle Eastern Dust (MED) storms in Ahvaz, Iran. Environ Pollut. 2016;211:316-24.

16. Wang GH, Wang H, Yu YJ, et al. Chemical characterization of water-soluble components of PM 10 and PM 2.5 atmospheric aerosols in five locations of Nanjing, China. Atmos Environ. 2003;37(21):2893-902.

17. Liu H, Wu Y, Chen M, et al. Characteristics of atmospheric PM2.5 in Nanjing City and its cytotoxicity in human lung epithelial cells A549. Res Environ Sci. 2018:31(10):1736-42

18. Sánchez-Pérez Y, Chirino Yl, Osornio-Vargas ÁR, etc. DNA damage response of A549 cells treated with particulate matter (PM10) of urban air pollutants. Cancer Lett, 2009,278(2):192-200

19. Kouassi KS, Billet S, Garçon G, etc. Oxidative damage induced in A549 cells by physically and chemically characterized air particulate matter (PM2.5) collected in Abidjan, Côte d'Ivoire. J Appl Toxicol, 2010, 30(4): 310-320.

20. Zou Y, Jin C, Su Y, etc. Water soluble and insoluble components of urban PM2.5 and their cytotoxic effects on epithelial cells (A549) in vitro. Environ Pollut,2016,212: 627-635.

21. Kim W, Jeong SC, Shin C. etc. DNA damage in A549 cells exposed to different extracts of PM(2.5) from industrial, urban and highway sites. Mol Cell Toxicol. 2018;14:163-72.

22. Abbas I, Verdin A, Escande F. etc. In vitro short-term exposure to air pollution PM2.5-0.3 induced cell cycle alterations and genetic instability in a human lung cell coculture model. Environ Res. 2016;147:146-58.

23. Longhin E, Holme J, Gutzkow KB, etc. Cell cycle alterations induced by urban PM2.5 in bronchial epithelial cells: characterization of the process and possible mechanisms involved. Part Fibre Toxicol, 2013, 10(1):63.

24. Gualtieri M, Øvrevik J, Mollerup S. etc. Airborne urban particles (Milan winter-PM2.5) cause mitotic arrest and cell death: Effects on DNA mitochondria, AhR binding and spindle organization. Mutat Res-Fund Mol M. 2011;713:18-31.

25. Deng F, Guo X, Liu H. etc. Effects of dust storm PM2.5 on cell proliferation and cell cycle in human lung fibroblasts. Toxicol in Vitro. 2007;21:632-8.

26. Yang J, Huo T, Zhang X. etc. Oxidative stress and cell cycle arrest induced by short-term exposure to dustfall PM2.5 in A549 cells. Environ Sci Pollut Res. 2018;25(23):22408-19.
27. Knöbel Y, Glei M, Osswald K. etc. Ferric iron increases ROS formation, modulates cell growth and enhances genotoxic damage by 4 hydroxynonenal in human colon tumor cells. Toxicol in Vitro. 2006;20(6): 793-800.

28. Wool IG. Extraribosomal functions of ribosomal proteins. Trends Biochem Sci. 1996;21(5):164-5.

29. Zhang $X$, Wang W, Wang $H$, Wang MH, Xu W, Zhang R. Identification of ribosomal protein S25 (RPS25)-MDM2-P53 regulatory feedback loop. Oncogene. 2013;32(22):2782-91.

30. Kuroda K, Takenoyama M, Baba T. etc. Identification of ribosomal protein L19 as a novel tumor antigen recognized by autologous cytotoxic T lymphocytes in lung adenocarcinoma. Cancer Sci. 2010;101(1):46-53.

31. Hu YW, Kang CM, Zhao JJ, etc. LncRNA PLAC2 down-regulates RPL36 expression and blocks cell cycle progression in glioma through a mechanism involving STAT1. J Cell Mol Med, 2018, 22(1): 497-510.

32. $\mathrm{Xu} \mathrm{XL}$, Xiong $X \mathrm{X}$, Sun $\mathrm{Y}$. The role of ribosomal proteins in the regulation of cell proliferation, tumorigenesis, and genomic integrity. SCIENCE CHINA-Life Sci. 2016;59(7):656-72.

33. Lai MD, Xu J. Ribosomal Proteins and Colorectal Cancer. Curr Genomics. 2007:8:43-9

34. Lohrum MA, Ludwig RL, Kubbutat MH, Hanlon M, Vousden KH. Regulation of HDM2 activity by the ribosomal protein L11. Cancer Cell. 2003;3(6): $577-87$.

35. Dai MS, Lu H. Inhibition of MDM2-mediated p53 ubiquitination and degradation by ribosomal protein L5. J Biol Chem. 2004;279(43):44475-82.

36. Jin A, Itahana K, O'Keefe K, Zhang Y. Inhibition of HDM2 and activation of p53 by ribosomal protein L23. Mol Cel Bio. 2004;24(17):7669-80.

37. Chen D, Zhang Z, Li M, Wang W, Li Y, Rayburn ER, Hill DL, Wang H, Zhang R. Ribosomal protein $\mathrm{S} 7$ as a novel modulator of $\mathrm{p53}-\mathrm{MDM} 2$ interaction: Binding to MDM2, stabilization of p53 protein, and activation of p53 function[J]. Oncogene. 2007;26(35):5029-37.

38. Cho JH, Park JY, Shin SC, etc. Ribosomal protein S2 interplays with MDM2 to induce p53. Biochem Biophys Res Commun, 2020, 523(2): 542-547.

39. Kardos GR, Dai MS, Robertson GP. Growth Inhibitory Effects of Large Subunit Ribosomal Proteins in Melanoma. Pigment Cell Melanoma Res. 2014;27(5): $801-12$.

40. Deisenroth C, Franklin DA, Zhang YP. The Evolution of the Ribosomal Protein-MDM2-p53 Pathway. CSH Perspect Med. 2016;6:a026138.

41. Liu H, Luo Q, Cui H, et al. Sodium fluoride causes hepatocellular S-phase arrest by activating ATM-p53-p21 and ATR-Chk1-Cdc25A pathways in mice. Oncotarget. 2017;9(4):4318-37.

42. Khleif $S \mathrm{~N}$, Degregori J, Yee $\mathrm{C}$ L, etc. Inhibition of cyclin D-CDK4/CDK6 activity is associated with an E2F-mediated induction of cyclin kinase inhibitor activity. PNAS, 1996, 93(9): 4350-4354.

43. Timmers C, Sharma N, Opavsky R, etc. E2f1, E2f2, and E2f3 Control E2F Target Expression and Cellular Proliferation via a p53-Dependent Negative Feedback Loop. Mol Cel Bio, 2006, 27 (1) : 65-78.

44. Thrane EV, Refsnes M, Thoresen GH, Låg M, Schwarze PE. Fluoride-induced apoptosis in epithelial lung cells involves activation of MAP kinases p38 and possibly JNK. Toxicol Sci, 2001, 61(1): 83-91.

45. Li XB, Zhou AR, Yu WH, Chen XA. The Effect of Cerium Compounds on Two Cell Lines: Human Lung Cancer Cells and Human Gastric Carcinoma cells BGC-823. Chin J Biochem Mol Bio,1999,15(04): 651-654. (in Chinese).

46. Li XB, Zhou AR, Yu WH, Chen XA. Effect of Lanthanum Citrate on Two Cell Lines: Human Lung Cancer Cells PG and Human Gastric Carcinoma Cells BGC-823. J Chin R E Soc. 2000;18(02):156-9.(in Chinese).

47. He X, Zhang Z, Zhang H, Zhao Y, Chai Z. Neurotoxicological evaluation of longterm lanthanum chloride exposure in rats. Toxicol Sci. 2008;103(2): 354-61.

48. He M, Ichinose T, Yoshida Y. etc. Urban PM2.5 exacerbates allergic inflammation in the murine lung via a TLR2/TLR4/MyD88-signaling pathway. Sci Rep. 2017;7(1):11027.

49. Harlow E, Lane D, Bradford assay. CSH Protoc 2006(6). pii: pdb. prot4644 doi: 10.1101 / pdb. prot4644.

50. Vuong NQ, Breznan D, Goegan P. etc. In vitro toxicoproteomic analysis of A549 human lung epithelial cells exposed to urban air particulate matter and its water-soluble and insoluble fractions. Part Fibre Toxicol. 2017;14:39.

51. Kumar SS, Muthuselvam P, Pugalenthi V. etc. Toxicoproteomic analysis of human lung epithelial cells exposed to steel industry ambient particulate matter (PM) reveals possible mechanism of PM related carcinogenesis. Environ Pollut. 2018;239:483-92. 
52. Qin Z, Fu F, Xu ZW. etc. Effects of PM2.5 on Human Placental Trophoblast Cells by iTRAQ Combined with 2D LC-MS/MS. J Int Obstet Gynecol. 2017; 44(2):202-7.

\section{Publisher's Note}

Springer Nature remains neutral with regard to jurisdictional claims in published maps and institutional affiliations.

Ready to submit your research? Choose BMC and benefit from:

- fast, convenient online submission

- thorough peer review by experienced researchers in your field

- rapid publication on acceptance

- support for research data, including large and complex data types

- gold Open Access which fosters wider collaboration and increased citations

- maximum visibility for your research: over $100 \mathrm{M}$ website views per year

At BMC, research is always in progress. 